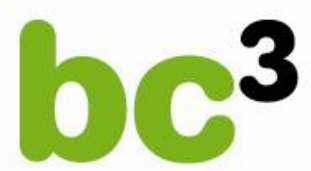

BASQUE CENTRE

FOR CLIMATE CHANGE

Klima Aldaketa Ikergai

\title{
From shadow to green: Linking environmental fiscal reforms and the informal economy
}

\author{
Mikel González-Eguino, Anil Markandya and Marta Escapa
}

March 2012

BC3 WORKING PAPER SERIES

2012-03 
The Basque Centre for Climate Change (BC3) is a Research Centre based in the Basque Country, which aims at contributing to long-term research on the causes and consequences of Climate Change in order to foster the creation of knowledge in this multidisciplinary science.

The BC3 promotes a highly-qualified team of researchers with the primary objective of achieving excellence in research, training and dissemination. The Scientific Plan of BC3 is led by the Scientific Director, Prof. Anil Markandya.

The core research avenues are:

- Adaptation to and the impacts of climate change

- Measures to mitigate the amount of climate change experienced

- International Dimensions of Climate Policy

- Developing and supporting research that informs climate policy in the Basque Country

See www.bc3research.org for further details.

The BC3 Working Paper Series is available on the internet at http://www.bc3research.org/lits_publications.html

Enquiries (Regarding the BC3 Working Paper Series):

Roger Fouquet

Email: roger.fouquet@bc3research.org

www.bc3research.org

The opinions expressed in this working paper do not necessarily reflect the position of Basque Centre for Climate Change (BC3) as a whole.

Note: If printed, please remember to print on both sides. Also, perhaps try two pages on one side. 


\title{
From shadow to green: Linking environmental fiscal reforms and the informal economy
}

\author{
Mikel González-Eguino $^{1}$, Anil Markandya ${ }^{1}$ and Marta Escapa ${ }^{2}$
}

In the past few decades many papers have analysed in some depth different environmental tax reforms and the double dividend hypothesis, i.e. the possibility of improving not only the environment but also the economy through the reduction of distortions in the tax system. Recently, more stress has been placed on testing empirically what effects a reduction in labour taxes may have on unemployment when accompanied by a carbon or other environmental tax. However, such studies have not modelled the effects of the presence of a shadow economy, even though informal markets account for a significant and growing part of GDP in many developed economies. This paper analyses this link using an Applied General Equilibrium model for the case of Spain, which has one of the highest unemployment rates in the world and one of the biggest informal economies of any wealthy country. We conclude that our analysis strengthens the case for an environmental tax reform in Spain if revenues from a CO2 tax are recycled via a labour tax reduction

Keywords: Environmental fiscal reform, double dividend hypothesis, shadow economy, unemployment, general equilibrium analysis, Spain

JEL Classification: D58, H2, Q5

Cite as: González-Eguino, M. Markandya A., Escapa, E. (2012). From shadow to green: Linking environmental fiscal reforms and the informal economy, BC3 Working Paper Series 2012-03. Basque Centre for Climate Change (BC3). Bilbao, Spain.

\footnotetext{
${ }^{1}$ Basque Centre for Climate Change (BC3), Alameda Urquijo, 4, 4 48008 Bilbao, Spain

${ }^{2}$ Dept. Fund. Análisis Económico I and Instituto de Economía Pública, University of the Basque Country, UPV/EHU, Spain

*The authors gratefully acknowledge financial support from Science and Innovation Ministry of Spain (ECO2011-25064) and Basque Government (GIC07/56-IT-383-07). We also thank Antonio Gomez-Plana and Dirk Ruebbelke for useful comments. Usual disclaimer applies.
} 


\section{Introduction}

The literature on environmental fiscal reforms is centred on the idea that environmental taxes produce not only improvements in the environment but also positive economic and social outcomes. In order to obtain this "double dividend" (Pearce, 1991), governments must use the revenues from environmental taxes to reduce the rates of other taxes in the economy. As long as environmental taxes are used to reduce rather than to replace other taxes the tax-interaction-effect has to be considered, which gives rise to the distinction between the "weak" and the "strong" double dividend hypotheses (Goulder, 1995). How governments recycle revenues from environmental taxes back into the economy is a key issue in determining the type and size of the double dividend.

The literature has focused, especially in Europe, on the possibility of reducing taxes on labour in order to reduce unemployment as a consequence of the environmental fiscal reform. The findings suggest that switching taxation from labour to energy/carbon can increase welfare, employment and reduce emissions but there are disagreements as to the size of these effects; Majochi (1996) and Markandya (2011) provide surveys of the quantitative studies. There are a great number of different models that focus on different characteristics of the labour market and show different restrictions and conditions that have to be met for a double dividend (in employment) to be found (see Bovenberg and Goulder 1996, Schneider 1997, Pissarides 1998, Bayindir-Upmann and Raith 2003 among others). One relevant point is whether involuntary unemployment is incorporated into the analysis or not (see Carraro et al 1996, Koskela and Shöb 1997, Manresa and Sancho 2005). In these circumstances there are two possible ways of increasing the demand for labour and reducing unemployment: (i) shifting the tax burden from workers to other groups (people on state benefits, living on capital income or from other countries); and (ii) improving the efficiency of the tax system by shifting taxation from labour to other factors such as capital, energy or carbon. 
To date however, this large body literature on the double dividend hypothesis includes no research on the link between the shadow economy and environmental fiscal reforms. This is an important gap considering that: i) labour taxes affect the decision whether to work in the formal or the informal sector; and ii) informal markets account for a significant and growing part of GDP in many developed economies. According to Schneider et al. 2010, in OECD countries the shadow economy accounted for between $12-33 \%$ in 2005 . Moreover, reducing the informal economy is an important policy target in itself because it creates significant economic problems such as efficiency distortions (allocation is determined not by productivity but by "fiscally effective" productivity), competition distortions (firms that pay taxes face higher costs and more regulation) and equity distortions (incomes not declared result in a loss of revenue for the public sector and a higher tax burden for those who pay taxes), among others. Although, admittedly, one of the main reasons for the lack of consideration of the informal economy in the economic models is lack of data, recent improvements in estimations (Schneider and Enste 2000, Schneider et al. 2010 or Schneider 2011 among others) suggest that it may be worth exploring this linkage.

In this paper we construct a model with the aim of shedding light on how a green fiscal reform can help to reduce the shadow economy and reducing unemployment. We analyse the effects of a revenue-neutral $\mathrm{CO} 2$ tax reform by focusing on the revenue-recycling effect. We compare the effects of using revenues from a $\mathrm{CO} 2$ tax to reduce taxes on labour, to reduce taxes on capital or to make lump sum transfers. We use a standard AGE model that contains two features which are important regarding the labour market. First, there is involuntary unemployment and wages are determined endogenously following a wage curve. And second, formal and informal labour (which are substitutes in the production function) are linked through an equilibrium condition where expected wages in the two sectors are set equal to each other. This idea is taken from Harris and Todaro (1970), who used it to explain rural-urban mobility, and the same approach has been used by Rutherford and Light (2002) in a CGE model for Colombia. 
We apply the model to Spain, which has a very high unemployment rate and one of the biggest informal economies (20-25\%) of any wealthy country. The results obtained for the (employment) double dividend in previous studies have traditionally been more optimistic for Spain than for other European countries (see Labandeira et al. 2004, Manresa and Sancho 2005 or Fæn et al. 2009), reflecting perhaps greater inefficiencies in the labour market ${ }^{2}$. The studies mentioned show that replacing part of labour taxation by a carbon tax would reduce unemployment and result in either a small loss of welfare or a small gain (as measured by the equivalent variation (EV)). A carbon tax would reduce not only $\mathrm{CO} 2$ emissions but also emissions of other local pollutants. The EV measure, however, does not take account of the benefits of reduced emissions of local pollutants. Therefore, in our analysis we estimate these benefits with recent damage estimates for air pollutants and add the relevant figures to the welfare gains from the environmental fiscal reform.

The paper is structured as follows. Section 2 discusses the relevance of the Spanish case study. Section 3 presents the algebraic model and the specificities of the labour market and Section 4 details the data used for calibration. Section 5 presents the results obtained from the different recycling schemes in the economy and in the environment. Finally, Section 6 concludes with some reflections on where further research is needed and provides some policy recommendations.

\section{The shadow economy and unemployment in Spain}

It is necessary to clarify what it is meant in this paper by "shadow economy", as there is no single precise and accepted definition of this concept. In fact, several different labels (shadow, informal, underground, irregular, hidden and subterranean) are used in reference to these economic activities. In this paper we follow the definition proposed by the OECD, which considers the shadow economy to include all production activities that are legal ${ }^{3}$ but deliberately concealed from public authorities in order to avoid: i) paying taxes or social security contributions; ii) meeting certain

\footnotetext{
${ }^{2}$ A comparison of some studies for Spain can be found in Markandya et al 2012.

${ }^{3}$ Illegal activities such as drug dealing, crime and human trafficking are not included. Activities such as some household services that legally do not need to be reported to authorities are also excluded.
} 
legal standards such as minimum wages, maximum hours, safety and health standards; or iii) complying with certain administrative procedures, such as completing statistical questionnaires or other administrative forms. A shadow economy thus implies a shadow or informal labour market. According to the OECD (2009) ${ }^{4}$ informal employment is the result of both people being excluded from official jobs and people voluntarily opting out of formal structures.

A comprehensive survey regarding definitions and estimation procedures for the shadow economy can be found in Schneider and Enste (2000) and Schneider (2011). One of the conclusions of these studies is that the main driving forces of the shadow economy are: i) tax and social security contribution burdens; ii) 'tax morale' or the intrinsic motivation of individuals to pay taxes; and iii) the intensity of state regulations. The bigger the difference between the total cost of labour in the official economy and after-tax earnings (from work), the greater the incentive is to avoid that difference and to work in the informal economy. However, it is not clear whether tax reforms with major tax rate deductions will lead to a substantial decrease of the informal economy or to a mere stabilisation. Social networks, personal relationships and lack of information are strong factors which prevent people from transferring easily to the official economy. Therefore, the way in which the mobility of workers between formal and informal labour is modelled and the assumptions regarding substitutability between them in the production function are significant.

According to recent estimations (Buehn and Schneider 2011) there is a significant shadow economy all over the world, and even in developed economies ${ }^{5}$ its size may be noteworthy. Estimates for developed countries range between eight and thirty percent of GDP (see Table 1). The countries of southern Europe, including Spain, have historically topped the informal economy rankings, though Scandinavian countries also tend to have large shadow economies (16-18\%). In

\footnotetext{
${ }^{4}$ At the world-wide level, informal jobs are the norm or the normal case: 1.8 billion people work in informal jobs, compared to 1.2 billion who enjoy formal contracts and social security protection (OECD, 2009).

${ }^{5}$ The shadow economy is generally smaller in developed countries than in developing countries. For example in Latin America and Sub-Saharan Africa it is estimated to be between 30 and $40 \%$.
} 
the case of Spain, Arrazola et al. (2010) estimate the size of the shadow economy using various methods. They conclude that for the period 2005-08 the shadow economy accounted for $21.5 \%$ of GDP with a loss of tax revenue for the government of 7\% of GDP. In Spain the shadow economy has grown steadily from around $12 \%$ in the period $1980-1984^{6}$. These results are in line with those of Buehn and Schneider (2011), who find that the average shadow economy in Spain was 22.5\% of GDP from 1999 to 2007.

Table 1: Size of the shadow economy in some developed countries, 2005 (\% of GDP)

\begin{tabular}{lr}
\hline Greece, Italy, Spain, Portugal and Belgium & $21-29 \%$ \\
Norway, Sweden, Denmark, Ireland, France, \\
The Netherlands, Germany and Great Britain \\
Japan, Austria, United States and Switzerland \\
\begin{tabular}{lr} 
Spain (Arrazola et al 2011) \\
\hline
\end{tabular} \\
\hline Source: Buehn and Schneider 2011 and Arrazola et al 2011
\end{tabular}

Feld and Schneider (2010) and Bajada and Schneider (2009) have also shown the role of the formal economy and unemployment in determining people's decisions on whether to work in the formal or informal sector. When growth in GDP is low or GDP is not increasing and unemployment is increasing, more people try to offset loss of income from the official economy through additional shadow economy activities. So normally the higher is unemployment the more people will engage in shadow economy activities and, therefore, the bigger will be the informal labour force. In many cases, a worker who is accounted for as unemployed (and sometimes even receiving unemployment benefits) is actually working in the informal sector so different measures of unemployment should be used. In this paper we consider the official and real measures of unemployment, with the difference between them being due to those who work in the informal sector.

\footnotetext{
${ }^{6}$ A detailed explanation of the patterns of the underground economy in Spain during the 1980s can be found in Ahn and de la Rica (1997).
} 
In this respect, Spain has one of the highest "official" unemployment rates in Europe and in any OECD country. Spain's unemployment problems have been severe since the second half of the 1970s. As Figure 1 shows, unemployment exceeded 20\% in the mid 1980s and 1990s. Although the rate subsequently decreased to $8.5 \%$ in 2007 , it has again increased sharply with the current economic recession.

Figure 1: Unemployment rates in some developed countries, 1983-2010

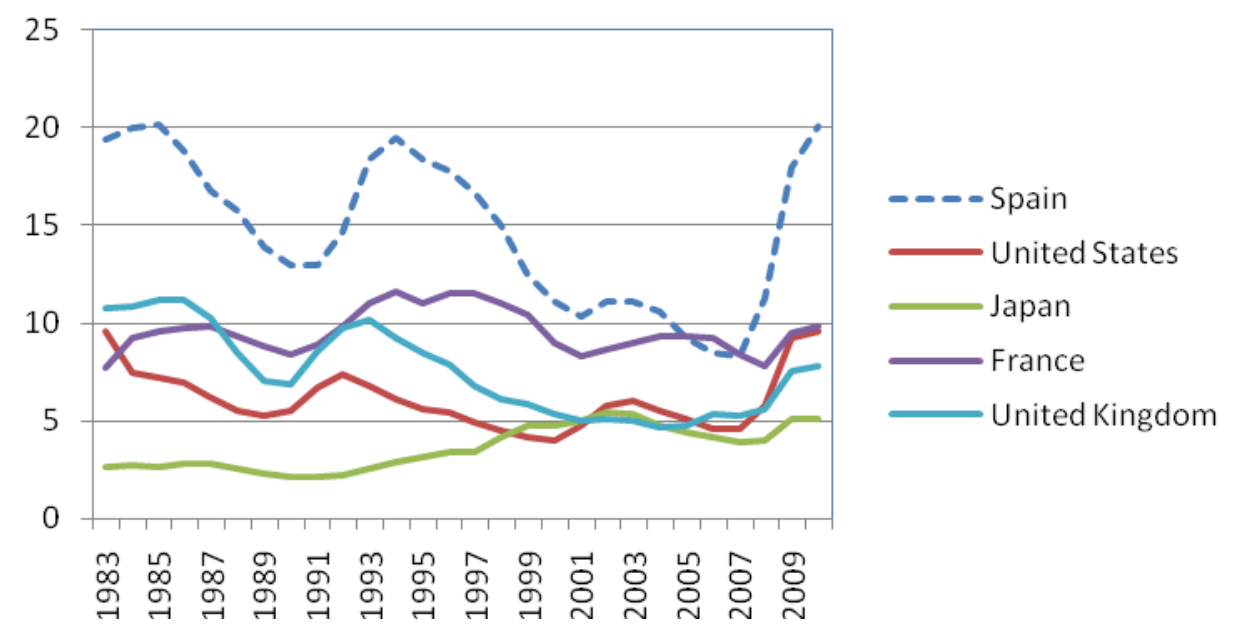

Finally, it is important to mention that there has been very little use of environmental taxes in Spain compared with other European countries. Apart from fuel and transport taxes (which were not originally conceived as environmental taxes) and the European Trading Scheme (EU-ETS), which put a price on $\mathrm{CO} 2$ in some sectors, the main instrument has been the granting of tax deductions for investments in environmental protection. In fact, environment-related revenues decreased from $2.6 \%$ of GDP in 1995 to $1.8 \%$ in 2007 , with taxes on pollution and resources being almost nonexistent.

The combination of its lack of environmental taxes, large shadow economy and high unemployment rate make Spain an interesting case study for analysing how an environmental fiscal reform can help policymakers to address current environmental and economic problems simultaneously. 


\section{The model}

In this section we present the detailed algebraic description of the model. We use a standard static multi-sector general equilibrium model for an open economy, as presented in section 3.1 (see Gonzalez-Eguino (2011) for more detail). The innovative feature of the model is the incorporation of the shadow economy through a formal-informal labour market. The specificities of the labour market are presented in section 3.2

\subsection{A standard AGE model}

Applied General Equilibrium (AGE) models are empirical versions of Arrow and Debreu models (Shoven and Whalley 1992). A standard AGE model can be described by a set of economic agents - households and firms - that demand and supply different goods, behave rationally and make choices based on solving their respective optimisation problems. Three classes of conditions characterise a competitive equilibrium: zero profit conditions, market clearance conditions and income balance conditions. Firstly, producers operate normally under full competition and maximise profit subject to given prices and current technology. Under constant returns to scale net profits are zero; the value of output must equal the value of all inputs used (zero profit condition). Secondly, consumers have an initial endowment of factors and maximise utility subject to the budget constraint; the value of income must equal the total value of expenditures (income balance condition). Finally, equilibrium is characterised by a set of equilibrium prices such that demand equals supply for all commodities simultaneously (market clearance condition). In this situation agents cannot do better by altering their behavior, given the prices and income constraints they face.

The model that we are using comprises the following: (1) 9 production sectors; (2) a representative consumer; (3) a government which collects taxes and supplies goods and services; and (4) the "Rest of the World", an aggregate that brings together foreign sectors. Primary factors are capital (K), formal labour $\left(\mathrm{L}^{\mathrm{F}}\right)$, informal labour $\left(\mathrm{L}^{\mathrm{I}}\right)$ and the energy factors: coal, fuel oil, gas, and electricity. 
All production factors are assumed to be homogenous and perfectly mobile between sectors, but labour and capital are only mobile domestically. There can also be mobility between the formal and informal labour markets, as explained below.

\subsubsection{Producers}

Each production sector $j=1, \ldots, J$ produces a homogenous good with a technology characterised by nested CES functions ${ }^{7}$. The output of each sector $\left(Y_{j}\right)$ is obtained by combining intermediate inputs $\left(Y_{i, j}^{I D}\right)$, which includes energy factors, capital $\left(K_{j}\right)$, formal labour $\left(L_{j}^{F}\right)$ and informal labour $\left(L_{j}^{I}\right)$. Equation 1 shows a simplified form of this output function, and Figure 1 depicts its structure in graphic form. The elasticities of substitution between different inputs are denoted by $\sigma$ (see Appendix).

$$
Y_{j}=f_{C E S}\left(Y_{1, j}^{I D}, \ldots, Y_{J j}^{I D}, K_{j}, L_{j}^{F}, L_{j}^{I}\right)
$$

Figure 1: Output nested CES function structure

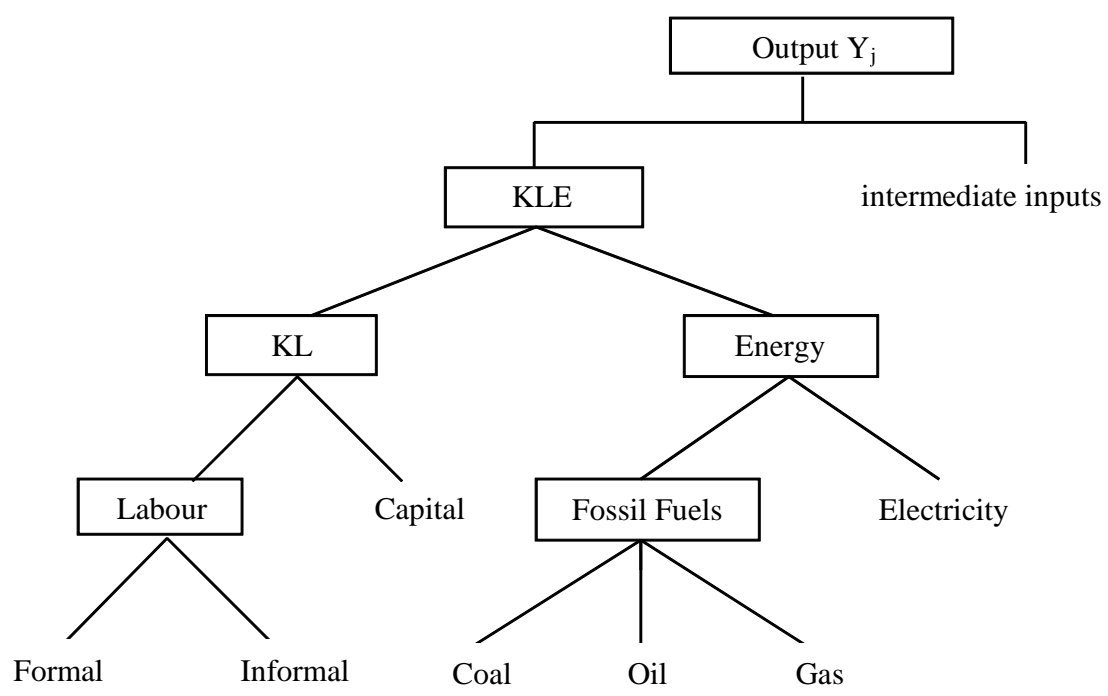

Producers maximise profit, subject to technological constraints. At equilibrium, net profit after tax would be zero, i.e. the value of the output from each sector would be equal to the sum total value of

\footnotetext{
${ }^{7}$ The following acronyms are used to indicate the functional form in place: LT (Leontief); CD (CobbDouglas), CES (Constant Elasticity of Substitution) and CET (Constant Elasticity of Transformation).
} 
the inputs. This condition is reflected in equation 2 , where $p_{j}$ is the price of the output from sector $j, p_{K}$ is the price of capital and $w_{F}$ and $w_{I}$ are the price of formal and informal labour. Sectoral tax rates on capital and formal labour are denoted by $t_{j}^{K}$ and $t_{j}^{L}$, respectively. Finally, there is a tax on $\mathrm{CO} 2\left(t^{E}\right)$ where $E_{j}^{P}$ represents the $\mathrm{CO} 2$ emissions in sector j.

$$
\sum_{i=1}^{J} Y_{i, j}^{I D} p_{j}+\left(p_{K}+t_{j}^{K}\right) K_{j}+\left(w_{F}+t_{j}^{L}\right) L_{j}^{F}+w_{I} L_{j}^{I}+t^{E} E_{j}^{P}=Y_{j} p_{j}
$$

\subsubsection{Consumers}

The model considers a representative consumer, who owns the production factors. Consumer preferences are defined by a utility function from among the various consumer goods $j$ and their corresponding elasticities of substitution (see Figure 2).

Figure 2: Utility nested CES function structure

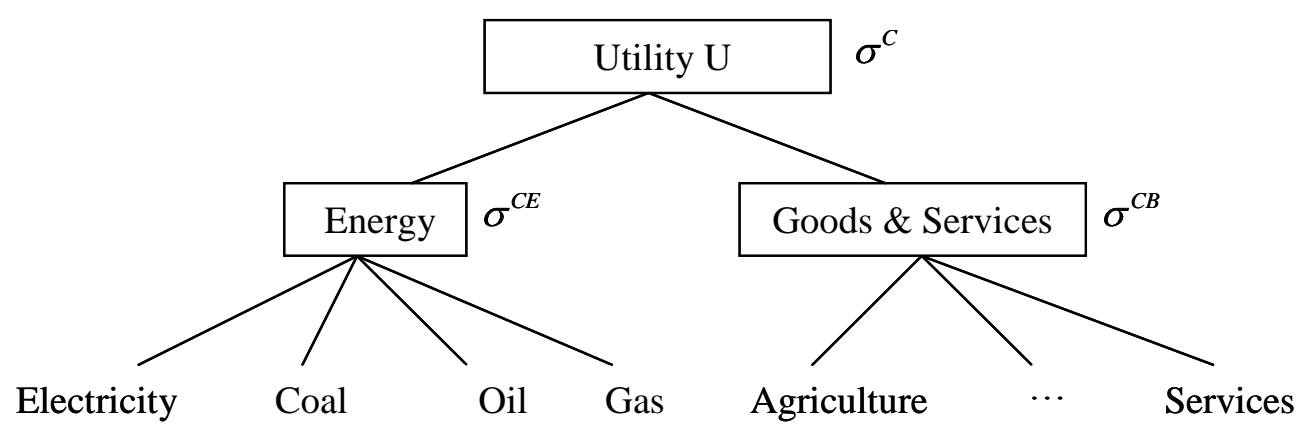

The consumer maximises his/her total utility (U) subject to his/her budgetary constraints:

$$
\begin{gathered}
\max U\left(C_{j}\right)=f_{C E S}\left(C_{1, \ldots,} C_{J}\right) \\
\text { s.t. } p_{K} K_{j}+w_{F} L_{j}^{F}+w_{I} L_{j}^{I}+T=C_{j} p_{j}+S+t^{E} E^{C}
\end{gathered}
$$


The income obtained from labour (formal and informal), capital and direct transfers from the government $(T)$ is equal to consumption $\left(C_{j}\right)$, savings $(S)$ and the payment for $\mathrm{CO} 2$ emissions from households ${ }^{8}\left(E^{C}\right)$. It is the savings of the representative consumer what enable investments and any foreign trade deficit to be financed.

\subsubsection{The Government}

The government obtains its income through taxes on capital, formal labour and $\mathrm{CO} 2$ emissions. This income is used by the government to provide public goods and services $\left(G_{j}\right)$ and to make direct transfers to consumers $(T)$. Government preferences are modelled via a Leontief function that enables the structure of public spending to be considered as fixed:

$$
\bar{G}=f_{\text {Min }}\left(G_{1}, \ldots, G_{J}\right)
$$

The additional income collected by the government from taxes on $\mathrm{CO} 2$ emissions is used to offset reductions in other taxes or an increase in transfers so that the level of public spending remains constant:

$$
\sum_{j=1}^{J}\left(t_{j}^{K} K_{j}+t_{j}^{L} L_{j}^{F}+t^{E} E\right)=\sum_{j=1}^{J} P_{j} \cdot G_{j}+T
$$

\subsubsection{The Foreign Sector}

To reflect trade with other regions we group all other countries into a single aggregate item referred to as the "Rest of the World" and we consider only imports and exports of goods and services.

\footnotetext{
${ }^{8}$ We tax all sources of $\mathrm{CO} 2$ emissions to guarantee cost-effectiveness, although in a real-policy context a $\mathrm{CO} 2$ tax could vary from sector to sector and also between producers and consumers. An instrument is costeffective when it is capable of attaining the target level at the least cost. In theory, these conditions are met when all economic agents face a common price, at the margin, for their contributions to emissions (Baumol and Oates, 1971).
} 
Two assumptions habitually made in AGEs are also made here. The first is the small open economy assumption, which establishes that (a) the domestic economy is too small to influence world-wide prices; and (b) import and export requirements can be met by trade with the Rest of the World. The second is the Armington assumption, which assumes that domestic and imported/exported goods are imperfect substitutes. In practice, this means modelling total supply $\left(Y_{j}^{T S}\right)$ as a CES function (see Equation 6) which aggregates domestic output $\left(Y_{j}\right)$, imports $\left(M_{j}\right)$ and total demand $\left(Y_{j}^{T D}\right)$, equal to total supply, by means of a transformation function or CET function (Equation 7), which breaks down total demand into domestic demand $\left(Y_{j}^{D}\right)$ and exports $\left(X_{j}\right)$.

$$
\begin{gathered}
Y_{j}^{T S}=f_{C E S}\left(Y_{j}, M_{j}\right) \\
Y_{j}^{T D}=Y_{j}^{T S}=f_{C E T}\left(Y_{j}^{D}, X_{j}\right)
\end{gathered}
$$

Finally, as a "closure rule" (Equation 8 ), we assume that the trade deficit $(\overline{X D})$, i.e. imports minus total exports, is constant, with $p_{X}$ being the adjustment variable.

$$
\sum_{j=1}^{J} p_{X}\left(M_{j}-X_{j}\right)=\overline{X D}
$$

\subsubsection{Emissions}

Emissions in this model are separated into two categories: i) $\mathrm{CO} 2$ emissions (E) linked to energy inputs consumption and ii) local emissions $\left(E L_{z}\right)$ linked to sectoral production output. The local emissions (denoted by index $z$ ) are: SO2, NOX, NMVOC, CH4, CO, N2O, NH3 and PPM ${ }^{9}$.

Total $\mathrm{CO} 2$ emissions $(E)$ are the sum of emissions from production sectors $\left(E^{P}\right)$ and consumers $\left(E^{C}\right)$. These emissions are associated via coefficients $\left(\alpha_{\theta}, \beta_{\theta}\right)$ with consumption of coal, oil and gas (denoted by the index e=3):

\footnotetext{
${ }^{9}$ Other emissions such as SF6, HFC and PFC are not included because there is no reliable disaggregation of them from sector to sector.
} 


$$
E=E^{p}+E^{C}=\sum_{\theta=1}^{3} \sum_{j=1}^{J}\left(\alpha_{e} \cdot Y_{\theta, j}^{I D}\right)+\sum_{\theta=1}^{3}\left(\beta_{e} \cdot C_{e}\right)
$$

Local emissions $\left(E L_{z}\right)$ are associated via specific coefficients $\left(\gamma_{z}\right)$ with output production:

$$
E L_{z}=\sum_{j=1}^{j} Y_{z} \cdot Y_{j}
$$

All emissions can be reduced by reducing output. In this model, $\mathrm{CO} 2$ emissions can also be reduced through energy substitution. Local pollutants can also be reduced through economic restructuring.

\subsubsection{Total Supply of Capital and Labour}

The total supply of capital and labour is considered to be exogenous. However, it is important to specify the relationship between investment and capital flows. The level of investment in an economy depends on interest rates, on the capital stock and on depreciation. These points cannot be incorporated into a static context, so we assume that investment at equilibrium must change with savings in such a way that the baseline share-out between savings and investment is maintained in the different simulations.

\subsubsection{Equilibrium and Solution}

The conventional Walrasian concept of equilibrium is used: the quantities supplied are equal to the quantities demanded, prices act as adjustment variables and all agents comply with their optimisation plans. In our case, this means equilibrium in the goods and services markets (Equation 11), in the labour and capital markets (Equations 12 and 13) and between savings and investment (Equation 14). 
$Y_{j}^{D}=\sum_{i=1}^{J}\left[Y_{j, i}^{I D}\right]+C_{j}+G_{j}+I_{j}+\left(M_{j}-X_{j}\right), \forall j \in(1, \ldots, J)$

$\bar{L}=\sum_{j=1}^{J}\left(L_{j}^{F}+L_{j}^{I}\right)$

$\bar{K}=\sum_{j=1}^{J} K_{j}$

$S=\sum_{j=1}^{J} P_{j} \cdot I_{j}+\overline{X D}$

\subsection{Labour market}

We wish to take into account the existence of informal labour and its relationship with unemployment and the shadow economy in Spain. For this reason we introduce some changes in the labour market equations, following the approach taken by Rutherford and Light (2002). Labour endowment is fixed ${ }^{10}$ in the model and it is assumed that it can be allocated to either "formal" or "informal" labour supply. Governments are able to collect taxes on formal labour but not on informal labour and the two factors are imperfect substitutes on the production side. Agents can choose how much of each type to supply and the level of informal labour used will determine the size of the shadow economy.

As shown in Figure 1, production sectors can substitute between formal and informal labour. The labour composite by sectors is modelled through a CES function as follows:

$$
L_{j}=\left(\delta_{j} L_{j}^{F^{(1-1 / \sigma)}}+\left(1-\delta_{j}\right) L_{j}^{\left.I^{(1-1 / \sigma L}\right)}\right)^{1 /\left(1-1 / \sigma_{L}\right)}
$$

\footnotetext{
${ }^{10}$ There is no labour-leisure choice in the model so all unemployment is involuntary.
} 
where $\delta_{\mathrm{j}}$ is the benchmark share of formal employment for sector $\mathrm{j}$ and $\sigma_{\mathrm{L}}$ is the constant elasticity of substitution between formal and informal labour. When the value of $\sigma_{L}$ is 0 there is no substitutability and the two factors should be combined in a fixed proportion. Conversely, formal and informal labour are substitutes when $\sigma_{L}$ is positive.

Unemployment in the formal market is determined by a wage curve where the real wage is a declining function of the rate of unemployment. According to Blanchflower and Oswald (1995, 2005), unemployment in the wage curve can be interpreted as the result of collective bargaining and is consistent with an efficiency-wage framework. In our model, the wage curve is given by the following equation:

$$
\frac{w_{F}}{P}=\left(\frac{u}{\bar{u}}\right)^{-\theta}
$$

where $\mathrm{u}$ is the unemployment rate, $\bar{u}$ is the unemployment rate at the benchmark, $\theta$ is an elasticity parameter that measures the sensitivity of the wage rate to the unemployment rate and $\mathrm{P}$ is the consumer goods price index. $\theta$ can be interpreted as a wage flexibility parameter. When $\theta=0$, the real wage is totally rigid and unemployment is perfectly flexible and, when $\theta \rightarrow \infty$, unemployment is totally rigid and the real wage is perfectly flexible. In other cases $(0<\theta<\infty)$ as $\theta$ increases, the sensitivity of the wage rate to unemployment increases.

The wage curve in the United States, where better data are available, has a long-run elasticity of approximately -0.1 , which means that a doubling of the unemployment rate is, historically, associated with a ten percent decline in the level of the (real) wage (Blanchflower and Oswald $1995,2005)$. The value of the parameter $\theta$ varies from one country and one time to another ${ }^{11}$. In countries like Spain, where the labour market has traditionally been more rigid (adjustments

\footnotetext{
${ }^{11}$ Blanchflower and Oswald (1995) shows the elasticities of wage curves for 12 countries. The figures vary between -0.04 (S. Korea) and -0.19 (Australia).
} 
normally take place through decreases in employment rather than wage reductions) the value of $\theta$ should be lower than elsewhere. In this paper, we consider an initial value of -0.1 and then conduct a sensitivity analysis of the parameter.

We take into account the possibility of workers moving between the formal and informal labour markets. Following Harris and Todaro (1970), workers move between formal and informal labour sectors until the informal wage $\left(w_{I}\right)$ is equal to the expected formal wage (equation 18). The expected formal wage is the formal wage $\left(w_{F}\right)$ times the employment rate $(1-u)$. As unemployment rises the gap between formal and informal wages widens. If unemployment is zero, formal and informal wages (before taxes) should eventually become equal ${ }^{12}$.

$$
w_{I}=w_{F}(1-u)
$$

We also include in the model an endogenous parameter $m$ which measures the mobility rate and determines formal and informal labour supplied in equilibrium.

$$
\begin{gathered}
L^{F}=L_{0}^{F}(1-u)+L_{0}^{I}(1-\mathrm{m}) \\
L^{I}=L_{0}^{I} m
\end{gathered}
$$

where $L_{0}^{F}$ and $L_{0}^{I}$ are the benchmark labour endowments for the formal and informal sectors. We need to include a variable such as $\mathrm{m}$ in the model so that the amounts of informal and formal labour can vary in response to unemployment and other market conditions in the formal sector.

\footnotetext{
${ }^{12}$ Some reviewers have noted that equation 18 does not hold empirically and there is a wedge between the two forms of labour even when accounting for unemployment. As long as that wedge is constant it can be incorporated in the above model with no loss of generality.
} 


\section{Data}

The initial equilibrium data come from the Symmetric Input Output Table (INE 2009a, see Table A1 and A2 in the Appendix). Emissions of pollutants for each sector are obtained from the Environmental Satellite Accounts (INE 2009b, see Table A3). Sectoral CO2 emissions disaggregated per energy input source (coal, oil and gas) are obtained from the energy balance sheets (Eurostat 2005, see Table A4). The reaction of agents to changes in economic policy is reflected through elasticities of substitution, which are taken from the MIT-EPPA model (Babiker et al. 2001, see Table A5).

The baseline size of the shadow economy is set at $20 \%$ of the official GDP, according to recent measures by Arrazola et al. (2010). This translates as around 4.3 million workers in the informal sector. It is commonly accepted that the percentage of undeclared work is higher in some sectors of the economy than in others, so in this paper we distribute informal activities between sectors assuming three types of sector according to their high, medium or low contribution to the shadow economic activity. The selection of sectors under each category and the level of informal labour are based on Hvidtfeldt $(2011)^{13}$. Finally, the official unemployment rate considered is $20 \%$. It is important to mention that the fact that the shadow economy and the unemployment rate are both $20 \%$ is a mere coincidence ${ }^{14}$.

\section{Results}

This section presents the results of different environmental tax reforms. The simulations look at $\mathrm{CO} 2$ taxes set to reduce emissions by amount ranging from 5\% to $30 \%$. The revenues from $\mathrm{CO} 2$ taxes are "recycled" via: (i) lump sum transfers (LST); (ii) reducing taxes on labour (TaxL); or (iii)

\footnotetext{
${ }^{13}$ Hvidtfeldt et al. (2011) use an interview survey to estimate the percentage of undeclared work for different sectors of the Danish economy in 2010. They find that $48 \%$ of the work done in the construction sector is undeclared, followed by agriculture (47\%), motor vehicle sales and repairs (43\%), manufacturing (36\%), transport and telecommunications (31\%) and hotel and restaurant (30\%).

${ }^{14}$ Estimations for the shadow economy in Spain range between 20 and 25\% depending on the method used (see Arrazola et al. 2010). In January 2012, the official unemployment rate in Spain was 23.5\%.
} 
reducing taxes on capital (TaxK). All these tax reforms are revenue neutral (government revenue is fixed) so welfare impacts can be compared. The results are presented as follows. Section 5.1 presents the economic impacts of the different "recycling" schemes. Section 5.2 analyses how these effects depend on different conditions in the labour market. Section 5.3 presents a sensitivity analysis of the key variables.

\subsection{Economic impacts of environmental tax reform}

First, we analyse welfare variations, measured in Equivalent Variation (EV), for the different recycling schemes. The EV welfare measure is limited to the economic source of welfare, which in this model is solely consumption. However welfare also depends on other issues such as environmental quality, so in Section 6 we provide an economic valuation of the effects of environmental tax reform on environment quality.

Table 1 and Figure 3 present the results when mobility is not allowed $\left(\sigma_{L}=0\right)$ and unemployment is fixed $(\theta \rightarrow \infty)$. As shown in Table 1, with the LST tax reform welfare decreases by around $0.09 \%$ for a reduction of $15 \%$ in $\mathrm{CO} 2$ emissions and by around 0.54 for a reduction of $30 \%$. A very small weak double dividend can be found if the reform reduces taxes on labour or capital, as welfare would be reduced only a little less. This weak double dividend depends on how distortionary the previous tax scheme was and on the magnitude of the tax interaction effect created. The more distortionary a tax, the more gains can be expected to be earned by reducing its rate. These results are in line with those models in the literature that do not incorporate unemployment and the shadow economy in their analyses. 
Figure 3. Welfare impacts with no mobility $\left(\sigma_{L}=0\right)$ and fixed unemployment $(\theta \rightarrow \infty)$

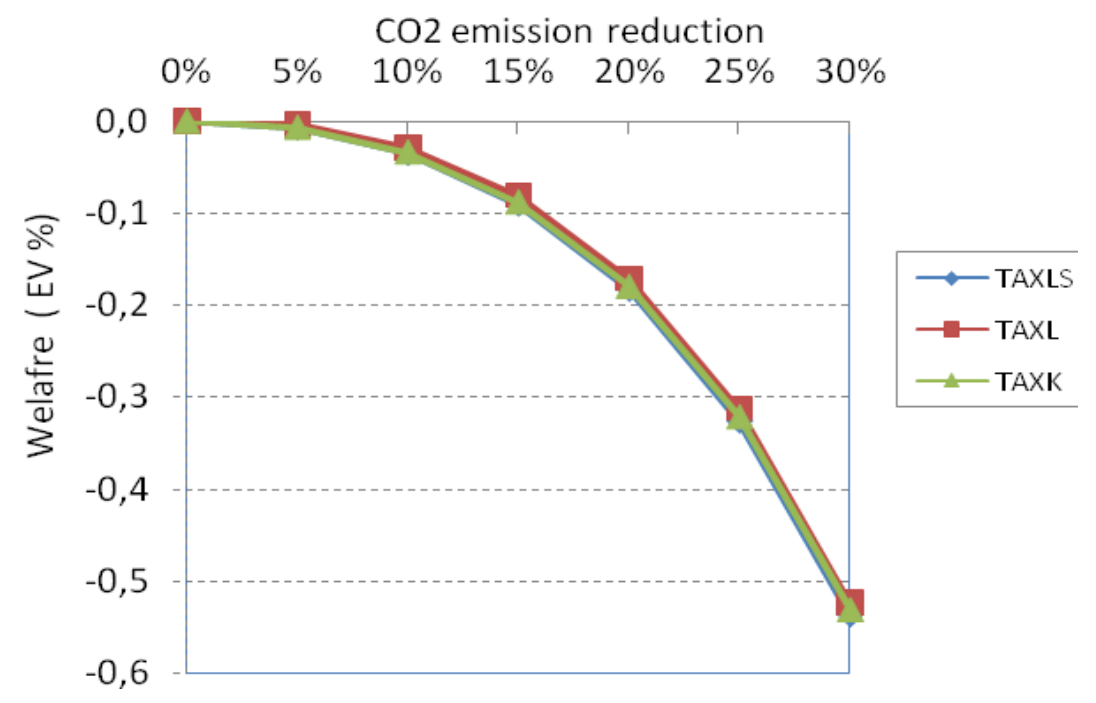

Table 1: Welfare impacts $(\%)$. No mobility $\left(\sigma_{L}=0\right)$ and fixed unemployment $(\theta \rightarrow \infty)$

\begin{tabular}{lcccccc}
\hline & \multicolumn{7}{c}{ CO2 Emission reduction (\%) } \\
Tax Recycling & $5 \%$ & $10 \%$ & $15 \%$ & $20 \%$ & $25 \%$ & $30 \%$ \\
\hline LST & -0.01 & -0.04 & -0.09 & -0.18 & -0.33 & -0.54 \\
TaxK & -0.01 & -0.03 & -0.09 & -0.18 & -0.32 & -0.53 \\
TaxL & 0.00 & -0.03 & -0.08 & -0.17 & -0.31 & -0.52 \\
\hline
\end{tabular}

However, it can be shown that the effects on welfare effects change considerably when mobility between formal and informal labour is allowed and the unemployment rate is not fixed, using the best estimations for the wage curve elasticity parameter $(\theta=0.1)$ and the elasticity of substitution between formal and informal labour $\left(\sigma_{L}=5\right)$. As can be observed in Table 2 and Figure 4, the welfare effects now depend strongly on the tax reform conducted and are much bigger. If revenues are used to reduce labour taxes, welfare increases: for a reduction of $15 \%$ in $\mathrm{CO} 2$ emissions the equivalent variation will be $2.8 \%$ higher than the benchmark figure. However, if revenues are used to reduce taxes on capital or given back with LST, welfare will decrease similarly by around $0.9 \%$. 
The effect on welfare is explained by the different effect that each reform has on the demand for labour. When the demand for labour increases, unemployment decreases and workers move from the informal to the formal sector. On the one hand, if unemployment is reduced there is a new endowment of labour that is now producing goods and services and, therefore, increasing welfare. On the other hand, if more workers are entering the formal economy there is a reduction in the deadweight loss (due to a smaller loss of government revenue from the informal sector). As a result, (official) GDP increases and the effective tax burden or fiscal pressure decreases, reducing the deadweight loss. However, if the demand for labour decreases unemployment may also increase and workers may also move to the informal sector, increasing the shadow economy and the deadweight loss. These changes in the demand for labour are mainly explained by the type of tax reform, because a reduction in the tax on formal labour (TaxL scenario) increases demand for it and increases the price of formal labour whereas the other reforms do not have this effect. However, the $\mathrm{CO} 2$ tax indirectly increases the demand for labour because it induces a restructuring of economic activity towards less $\mathrm{CO} 2$ intensive sectors (see Table 3), which are normally more intensive in labour and less in capital/energy.

One relevant effect that can be observed in Figure 4 is that the higher the $\mathrm{CO} 2$ tax (and the $\mathrm{CO} 2$ reduction target) is, the higher the welfare gains/losses are. This means that, in the context of this model, the important issue is not the size of the tax but the "recycling" scheme selected. A higher tax on $\mathrm{CO} 2$ implies more revenues that can be used to decrease labour taxation thus increasing even more the demand for labour and ultimately welfare. In fact, this positive effect on welfare is maintained up to the point where unemployment and the informal economy disappear ${ }^{15}$.

\footnotetext{
${ }^{15}$ In our model the limitation on additional reductions in emissions comes firstly from technology, which is exogenously given. As most emission reduction in the model stems from input substitution and economic restructuring, there is a maximum level of reduction that can be attained. Increasing emission reduction by more than $40 \%$ is not feasible given the elasticities of substitution obtained from the relevant literature.
} 
Figure 4. Welfare impacts. Mobility $\left(\sigma_{L}=5\right)$ and flexible unemployment $(\theta=0.1)$

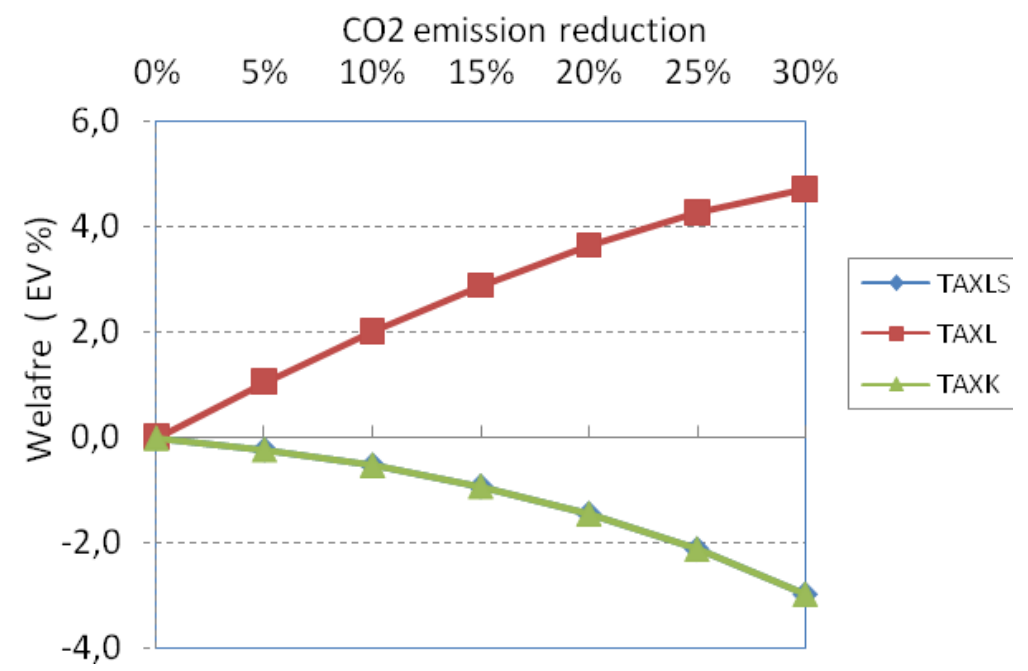

Table 3 shows how the different tax recycling schemes affect other relevant variables (such as GDP, unemployment, the shadow economy, energy consumption, etc.) for a reduction of $15 \%$ in $\mathrm{CO} 2$ emissions. It can be observed that if labour taxes are reduced, welfare will increase by $2.8 \%$, GDP by $2.6 \%$ but the official GDP (without the income generated by the informal labour) will increase by $7.6 \%$. This increase in official activity is explained by the reduction of both "official" unemployment (from $20 \%$ to $16.5 \%$ ) and "real" unemployment (from $10.9 \%$ to $10.8 \%)^{16}$ which means the incorporation of new workers into formal labour (the shadow economy decreases from $20 \%$ to $14.5 \%$ ). Moreover, as more workers pay taxes and government spending is fixed, the tax burden is also reduced. However, in the other recycling schemes (LST and TaxK), GDP falls as a consequence of increases in unemployment and in the shadow economy.

Table 2: Welfare impacts (\%). Mobility $\left(\sigma_{L}=5\right)$ and flexible unemployment $(\theta=0.1)$

\begin{tabular}{lrrrrrr}
\hline & \multicolumn{7}{c}{ CO2 Emission reduction (\%) } \\
Tax Recycling & $5 \%$ & $10 \%$ & $15 \%$ & $20 \%$ & $25 \%$ & $30 \%$ \\
\hline LST & -0.22 & -0.52 & -0.91 & -1.43 & -2.10 & -2.96 \\
TaxK & -0.21 & -0.51 & -0.91 & -1.43 & -2.10 & -2.96 \\
TaxL & 1.05 & 2.02 & 2.89 & 3.65 & 4.27 & 4.72 \\
\hline
\end{tabular}

16 "Official" unemployment includes both workers who are registered as unemployed and workers who are working in the informal sector. "Real" unemployment excludes informal workers. 
Table 3. Economic impacts of alternative tax recycling (15\% $\mathrm{CO} 2$ reduction)

\begin{tabular}{lrrr}
\hline & LST & TaxK & TaxL \\
\hline General (\% change in volumes) & & & \\
\hline Welfare & -0.91 & -0.91 & 2.89 \\
GDP (including shadow economy) & -0.83 & -0.83 & 2.62 \\
Official GDP & -1.55 & -1.55 & 7.65 \\
\hline General (values in \%) & & & \\
\hline (S) Shadow Economy (base=20\%) & $20.9 \%$ & $20.9 \%$ & $14.5 \%$ \\
(U) Unemployment (official, base=20\%) & $21.4 \%$ & $21.4 \%$ & $16.5 \%$ \\
(Ur) Unemployment (real, base=10.9\%) & $12.3 \%$ & $12.4 \%$ & $10.8 \%$ \\
Tax Burden (base=14.5\%) & $14.6 \%$ & $14.6 \%$ & $13.3 \%$ \\
\hline Private consumption (\% change in volumes) & & & \\
\hline Agriculture & -0.99 & -1.81 & 1.17 \\
Energy ${ }^{17}$ & -2.67 & -3.04 & 0.53 \\
Industry & -1.68 & -2.09 & 1.95 \\
Construction & -0.62 & -0.70 & 3.70 \\
Transport & -1.65 & -1.23 & 1.76 \\
Services & -0.32 & -0.21 & 3.74 \\
\hline Energy consumption by source $(\%$ change in volumes) & & \\
\hline Coal & -34.39 & -34.38 & -37.11 \\
Oil & -9.63 & -9.52 & -9.10 \\
Gas & -1.76 & -2.20 & 0.72 \\
Electricity & -2.77 & -2.92 & 0.06 \\
\hline Emissions (\% change in volumes) & -0.44 & 0.66 \\
\hline CO2 emissions & -1.55 & 2.26 \\
CO2 tax (€/tCO2) & 33.91 & 33.83 & 46.23 \\
\hline Prices (\% change) & & & \\
\hline Capital price index & & & \\
\hline
\end{tabular}

As shown in Table 3, the $\mathrm{CO} 2$ tax induces a change in the consumption of energy (in all three "recycling" scenarios) that is to some extent proportional to the carbon content of each fuel, where coal and oil are reduced more than gas and electricity. The results also show a shift from highly

${ }^{17}$ Energy good includes coal, oil, gas and electricity. 
CO2-intensive sectors (Energy, Industry and Transport) towards less $\mathrm{CO} 2$ emission-intensive sectors (Services). The $\mathrm{CO} 2$ taxes required to reach the $\mathrm{CO} 2$ targets are around $€ 33 / \mathrm{tCO} 2$ in the LST and TaxK scenarios, and $€ 46 / \mathrm{tCO} 2$ in the TaxL scenario. The tax needs to be higher in the TaxL scenario because under this reform economic activity increases, and therefore so do emissions. Finally, the (relative) prices of capital, formal labour and informal labour are presented. In general, as long as $\mathrm{CO} 2$ taxes increase the (relative) price of energy increases and, therefore, the prices of other production factors (labour and capital) decrease ${ }^{18}$. However, the final effect on prices in a general equilibrium model depends on complex interaction effects because: (i) the general activity level of the economy determines the demand for goods; (ii) the structural change induced in the economy determines the demand for factors; and (iii) the "recycling" scheme implemented also affects the demand for factors, as long as reducing TaxK increases the demand for capital and reducing TaxL increases the demand for labour. The final equilibrium prices show increases in the price of formal and informal labour in the TaxL scenario and a reduction in the TaxK and LST scenarios.

\subsection{The role of the shadow economy in the analysis of environmental tax reforms}

Section 5.1 above analyses the effect of different tax reforms and concludes that a reduction in labour tax may generate positive effects on welfare and on many other economic indicators. These positive effects are due to a combination of two different, although related, effects: 1) reduction in unemployment (workers moving from unemployment to employment); and 2) reduction in the shadow economy (workers moving from informal to formal work). In this section we separate these two effects in an effort to shed light on the contribution of considering the shadow economy in an environmental fiscal reform analysis. We focus on the case of the TaxL reform for a reduction of emissions of $15 \%$.

\footnotetext{
${ }^{18}$ In an AGE model all prices are relative prices. In our case, the general price index (the price of utility) is the numeraire and it is exogenously determined and equal to one in the simulations. In this way, changes in utility can be interpreted as equivalent variations.
} 
Figure 5 shows the changes in the main economic variables under four different scenarios where mobility between formal and informal labour is allowed (M) or not (Mfx) and where unemployment is assumed to be fixed (Ufx) or flexible (U). Mobility is fixed when $\sigma_{\mathrm{L}}=0$ and unemployment is fixed when $\theta \rightarrow \infty$.

The results in the blue bar (mobility not allowed and unemployment fixed) and in the purple bar (mobility allowed and unemployment flexible) are analysed in the previous section. The most interesting part of Figure 5 is the comparison i) between the red and the green bar (which enables a comparison to be drawn between two new different labour market conditions); and ii) between the red bar and the purple bar (which enables a comparison to be drawn between the extra benefits that could be obtained if the shadow economy were incorporated into the existing literature on environmental fiscal reforms and the double dividend hypothesis).

Firstly, the comparison between the red and green bars (mobility fixed and unemployment flexible versus mobility allowed and unemployment fixed) shows that the welfare effect is very similar in both cases (increases of 1.4 and 1.5\%). In the case of fixed mobility (the red line) the shadow economy is almost the same ${ }^{19}$ and all the benefits are due to workers coming off unemployment. Therefore, the changes in official and real unemployment rates are equal (-15.8\%). But in the case of fixed unemployment (green line) the welfare gains are obtained because informal workers are brought into formal labour and this reduces the shadow economy $(-18.9 \%)$ and the measured level of official unemployment $(-7.3 \%)$, but not real unemployment. Therefore, although the welfare effects are almost the same the sources of those effects are different and, importantly, the economic and social implications of the two effects are not the same. Although we cannot explore these implications with our model, it is clear that it is not the same to have more people unemployed and less in the shadow economy as vice versa.

\footnotetext{
${ }^{19}$ The small reduction in the shadow economy, from 20 to $19.7 \%$, is obtained because the overall economy grows and therefore the share accounted for by informal activity decreases.
} 
Secondly, from the comparison between the red and purple bars (mobility fixed and unemployment flexible versus mobility allowed and unemployment flexible) we estimate an extra amount of welfare of $1.5 \%$ (1.3 vs. $2.8 \%$ ). The extra GDP would be $1.4 \%$ (1.2 vs. $2.6 \%)$, though in terms of official GDP it would be $6.1 \%$ (1.5 vs. $7.6 \%)$. Most of these extra benefits come from a major reduction in the shadow economy but also from a greater reduction in formal unemployment.

The results in this section confirm that labour market conditions are important when analysing an environmental fiscal reform that affects labour taxes. Moreover, we show that, considering the impacts, shadow economies are too significant not to be considered.

Figure 5. Effect of TaxL scenario under different labour market conditions (15\% reduction in CO2)

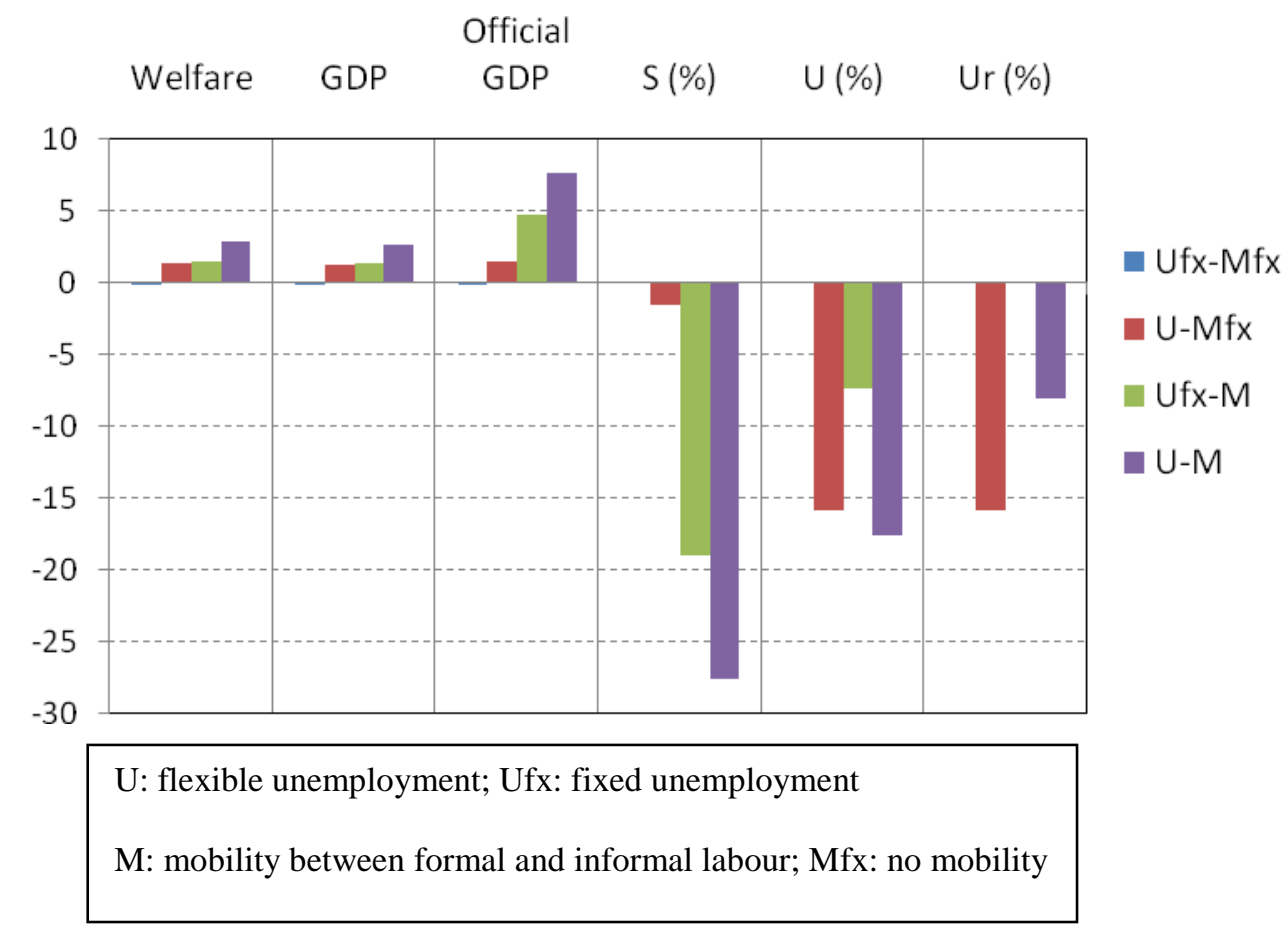

\subsection{Sensitivity analysis}

In this section we explore the robustness of our results with a systematic sensitivity analysis of the key parameters of the model. We explore the impact of an increase/decrease of $50 \%$ in the benchmark value for the following parameters: size of the shadow economy $\left(\mathrm{S}_{\mathrm{o}}\right)$, size of official 
unemployment $\left(\mathrm{U}_{0}\right)$, unemployment flexibility $(\theta)$, and substitutability between formal and informal labour $\left(\sigma_{L}\right)$. We also explore an alternative sectoral distribution of the shadow economy $\left(\delta_{j}\right)$ due to the lack of accurate data. In all the sensitivity analyses we focus on the TaxL reform and its welfare effect.

\subsubsection{Size of the shadow economy $\left(S_{0}\right)$}

Here we explore the impact of environmental fiscal reform on welfare for different sizes of the shadow economy $\left(\mathrm{S}_{0}\right)^{20 .}$ The benchmark value for the shadow economy is $20 \%$ (similar to Belgium, Portugal and Sweden). We consider values for a shadow economy of $10 \%$ (similar to Japan, the United States and the United Kingdom) and of 30\% (similar to Turkey, Mexico and Malaysia). A ranking of the shadow economy in 162 countries from 1999 to 2007 can be found in Schneider et al (2011).

Figure 6. Welfare impacts (\%) for different sizes of the shadow economy

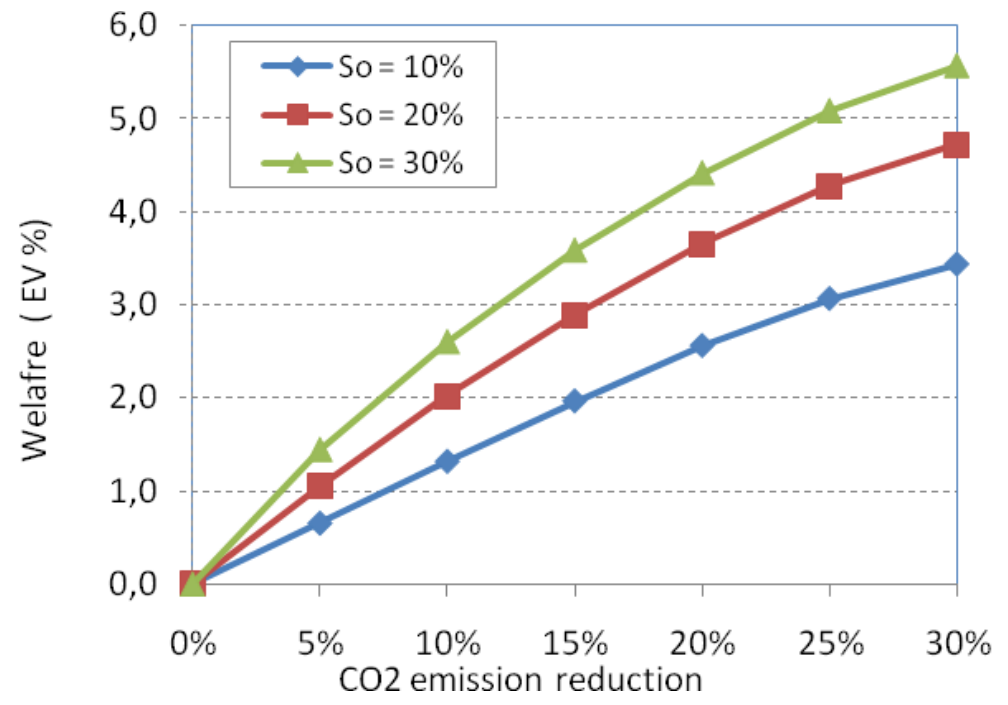

Figure 6 shows the welfare effects $(\mathrm{EV} \%)$ of different values of $\mathrm{S}_{0}$ and different $\mathrm{CO} 2$ emission reduction targets in the case of reducing labour taxes (TaxL). As analysed extensively in previous sections, welfare increases with an increasing $\mathrm{CO} 2$ target/tax. The different sizes of the benchmark

\footnotetext{
${ }^{20}$ To perform this sensitivity analysis two new different Input-Output Tables were constructed where the sum total of the row of the "informal labour" sector is increases/decreases to obtain the shadow economy desired.
} 
shadow economy however change the size of this effect. The higher the shadow economy (the green line) the higher the welfare increase is and the lower the shadow economy (the red line) the lower the welfare increase is. For a CO2 reduction of $15 \%$, the welfare in the benchmark increases by $2.9 \%$, but it increases by $2.0 \%$ in the low scenario and 3.6 in the high scenario. For a reduction of $30 \%$ in emissions welfare increases a little, from $4.7 \%$ in the benchmark to $3.4 \%$ and $5.6 \%$ in the low and high scenarios.

Therefore, the bigger is the shadow economy is, the higher are the expected welfare gains. There are more potential workers that can move from the informal economy to the formal and the benefits from decreasing the tax burden and reducing the deadweight loss are also higher. Of course, this does not mean that is better to have a high shadow economy: it means that reforms of this type produce greater benefits in those countries where the initial situation is more inefficient.

\subsubsection{Official unemployment rate $\left(\mathbf{U}_{0}\right)$}

In this section we explore the impact of welfare for different official unemployment rates $\left(U_{o}\right)$. The benchmark value for the official unemployment rate is $20 \%$ and we analyse alternative rates of $10 \%$ and $30 \%$. Although unemployment rates of $30 \%$ are very rare, we perform this analysis in order to be consistent with the sensitivity analysis of an increase/decrease of $50 \%$ in the benchmark value.

Figure 7 shows the welfare effects $\left(\mathrm{EV} \%\right.$ ) of different values of $\mathrm{U}_{0}$ and different $\mathrm{CO} 2$ emissions reduction targets in the case of reducing labour taxes (TaxL). It can be observed that the higher (lower) the unemployment rate the higher the welfare increase is. This is because, as in the case of a higher shadow economy, the higher the unemployment rate is the more potential workers can move from unemployment to employment and the greater the potential benefits that can be obtained. 
For a $\mathrm{CO} 2$ reduction of $15 \%$ the welfare in the benchmark case increases by $2.9 \%$, but it increases by $1.8 \%$ in the low scenario and $3.8 \%$ in the high scenario. For a reduction of $30 \%$ in emissions, welfare increases from $4.7 \%$ in the benchmark case to $2.9 \%$ and $6.3 \%$ in the low and high scenarios.

\section{Figure 7. Welfare impacts for different official unemployment rates}

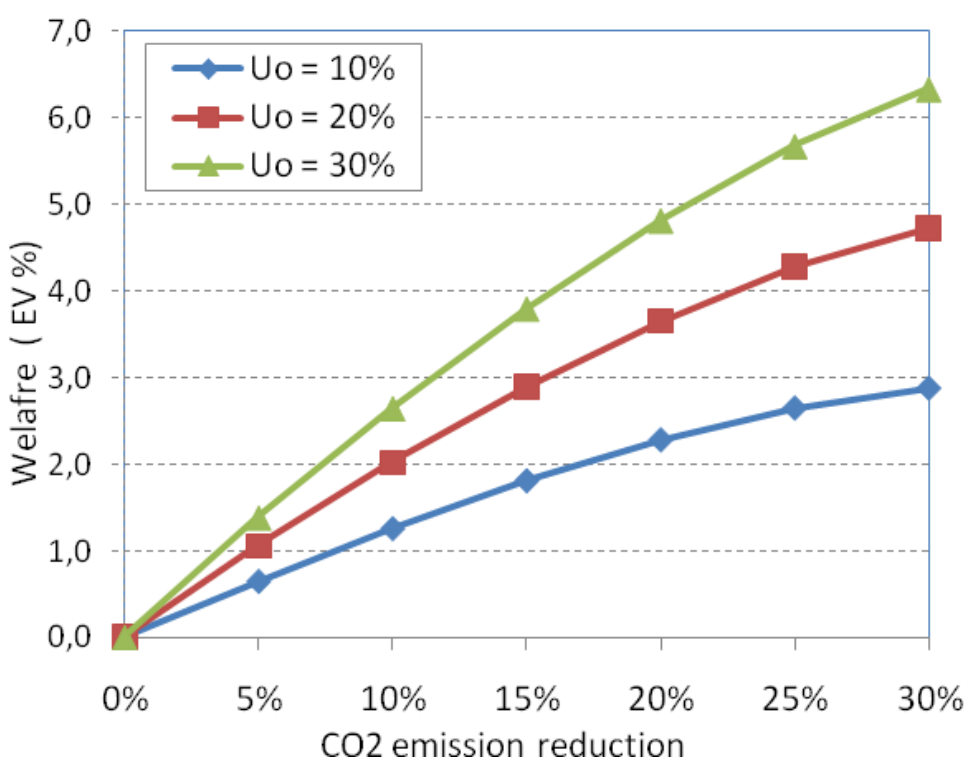

\subsubsection{Wage curve elasticity parameter $(\theta)$}

In this section we explore the impact on welfare of different values of the wage curve elasticity parameter $(\theta)$. The benchmark value of this parameter is 0.1 and we analyse the values 0.05 and 0.15, within which most countries are located according to Blanchflower and Oswald $(1995,2005)$. We also consider the extreme situations where $\theta=0$ (real wage totally rigid and unemployment perfectly flexible) and $\theta \rightarrow \infty$ (real wage perfectly flexible and unemployment totally rigid). 
Figure 8. Welfare impacts for different values of labour market flexibility $(\theta)$

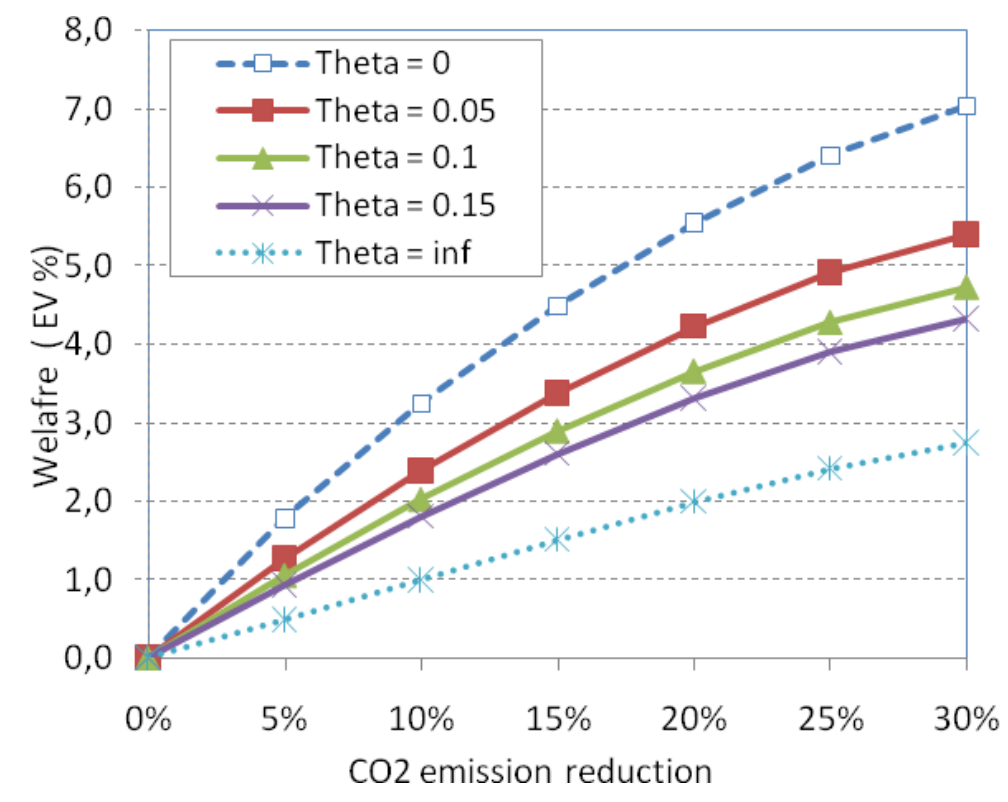

Figure 8 shows the welfare effects (EV \%) for different values of theta $\theta$. The greater the value of this parameter the lower the welfare gain is. For a $\mathrm{CO} 2$ reduction of $15 \%$ the welfare in the benchmark case increases by $2.9 \%$, but it increases by $3.4 \%$ in the low scenario (the red line) and 2.6 in the high scenario (the purple line). This result increases much more if the more extreme situation is considered, ranging from $1 \%$ to $4.5 \%$ for a reduction of $15 \%$.

Therefore, the more "flexible" the labour market is (in terms of the possibility of reducing/increasing real wages instead of increasing/decreasing unemployment), the lower the welfare gains expected from tax reform are. Of course, we are not saying that it is better to have a "rigid" labour market: if we already have a "rigid" labour market the potential benefits of the fiscal reform are greater. Finally, although we analyse the whole range of values for this parameter the results for the most likely range do not vary much, so it can be said that the results are not highly sensitive to this parameter.

\subsubsection{Formal and informal labor substitutability $\left(\sigma_{L}\right)$}


In this section we explore the impact on welfare of different values of elasticity of substitution between formal and informal labour $\left(\sigma_{L}\right)$. The benchmark value of this parameter is 5 and we analyse the values 2.5 and 7 , plus the extreme situation where the value is 0 , i.e. the two factors have to be combined in fixed proportions. The sensitivity analysis is necessary because there is no econometric estimation for this parameter, although other proxies such as the elasticity of substitution between skilled and unskilled labour could be used as a low range reference.

Figure 8 shows the welfare effects $(\mathrm{EV} \%)$ for different values of $\left(\sigma_{\mathrm{L}}\right)$. The greater the value of this parameter, the greater the welfare gain is. For a $\mathrm{CO} 2$ reduction of $15 \%$ the welfare in the benchmark case increases by $2.9 \%$, but it increases by $1.2 \%$ in the low scenario (the blue line) and $5.2 \%$ in the high scenario (the green line). The welfare gain decreases to $0.2 \%$ if no substitutability is considered (purple line).

Therefore, the more substitutability there is between the two forms of labour the greater is the expected increase in welfare because workers can move more easily to the formal labour market. Moreover, the value of this parameter is important because it has a considerable effect on the final results.

Figure 8. Welfare impacts for different values of labour market flexibility $(\theta)$

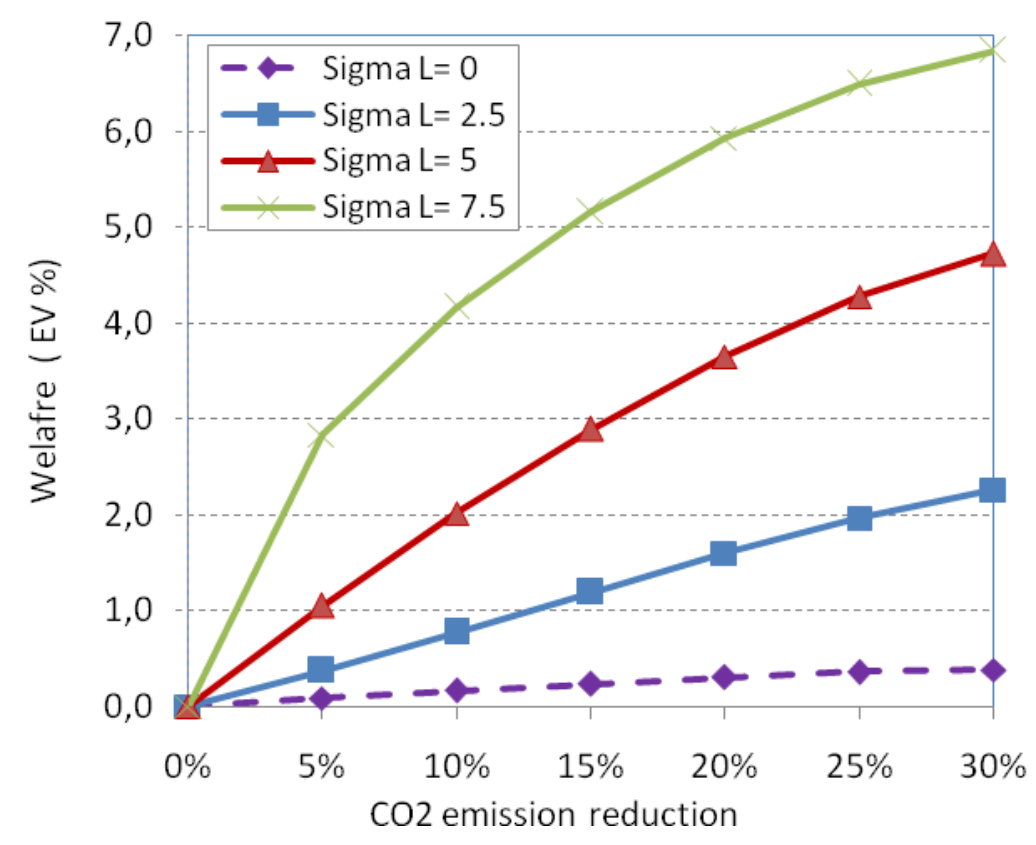




\subsubsection{Sectoral distribution of the informal economy $\left(\delta_{j}\right)$}

Finally, we explore how the sectoral distribution of the shadow economy (parameter $\delta_{j}$ ) affects the results. Most research in the field of the shadow economy research has focused on estimating its total size with different indirect methods (monetary, electricity consumption, etc.), but few papers report sectoral disaggregation. We compare the results of "benchmark distribution", which is based on a Danish study by Hvidtfeldt (2011), with a "uniform distribution" (blue line), i.e. total informal labour is distributed proportionally to formal labour.

Figure 9 shows that the welfare effects (EV \%) are very similar in the two distribution scenarios. For a $\mathrm{CO} 2$ reduction of $15 \%$ welfare increases by $2.9 \%$ in the benchmark distribution (red line) and 2.6 in the uniform distribution (blue line). Moreover, the greater the $\mathrm{CO} 2$ reduction target/tax the smaller this difference becomes, as the distribution of the shadow economy is not so important as other substitution effects. Therefore, although the distribution of the shadow economy obviously affects sectors, the overall effect is not very significant.

Figure 9. Welfare impacts for different values of labour market flexibility $(\theta)$

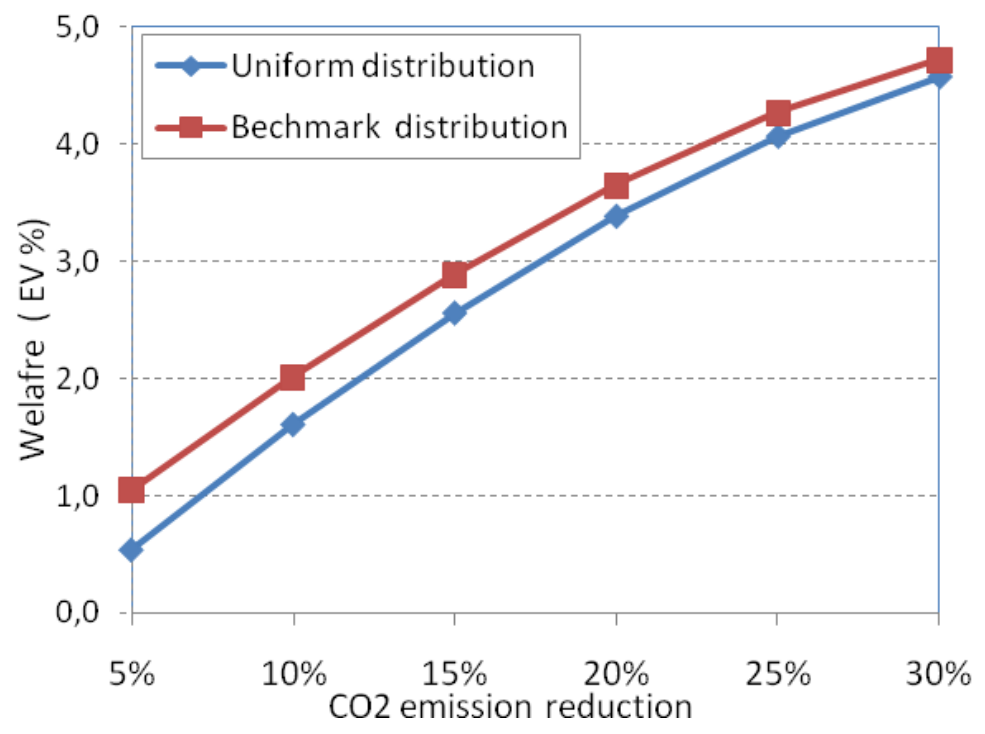




\section{Policy implications}

As seen in the introduction, the main policy recommendation from the surveys on environmental

fiscal reforms is that one of the best options is to replace taxes on labour by taxes on energy/CO2 because that way it is possible to reduce emissions, increase welfare and reduce unemployment. Moreover, this paper shows that these results would be even more positive if we take the shadow economy into account. Therefore, the next question is obviously why environmental tax reforms are not undertaken if they are so convenient. We look at four main barriers that may explain this paradox and show how including the shadow economy in the analysis could help to overcome them.

One reason is that people do not like paying new taxes, even if they are revenue neutral. Therefore, an important part of any environmental tax reform should be an effort by policy makers to explain to public opinion that -apart from the positive environmental and economic effects - government spending and the tax burden will not increase with the reform. In fact our analysis, which includes the shadow economy, has shown that the tax burden could be reduced as more people in the informal economy will start paying taxes.

Another reason is that a tax on $\mathrm{CO} 2$ will increase the price of energy and that will affect some industries. In fact some energy goods, such as gasoline, are already heavily taxed in many countries $^{21}$ and there is a fear that taxing $\mathrm{CO} 2$ will increase its price even more. Figure 10 shows how the (relative $\mathrm{e}^{22}$ ) price of different goods would change in our standard scenario ${ }^{23}$ with a $\mathrm{CO} 2$

\footnotetext{
${ }^{21}$ In the case of Spain fuel is relatively cheap compared to other European countries because of low excise duties. In the first quarter of 2009, Spain had the fourth-lowest petrol prices and the third-lowest diesel prices in Europe (IEA, 2009).

${ }^{22}$ In an AGE context prices are relative. Our reference price or numeraire is the price of utility (which can be considered as the consumer price index or CPI). This price can be kept constant with an increasing price of energy or other goods due to reductions in the prices of other goods such as services.
} 
tax of $€ 46.2$ per ton. The blue bar shows that the price of oil (petrol and gasoline) would increase by $3.9 \%$ and that the price of electricity would increase by $17 \%$. It could be argued that one possibility for overcoming this problem is to protect some "strategic" sectors or goods.

\section{Figure 10. Price variations of different price exemptions for the TaxL scenario and a $15 \%$ reduction in $\mathrm{CO} 2$}

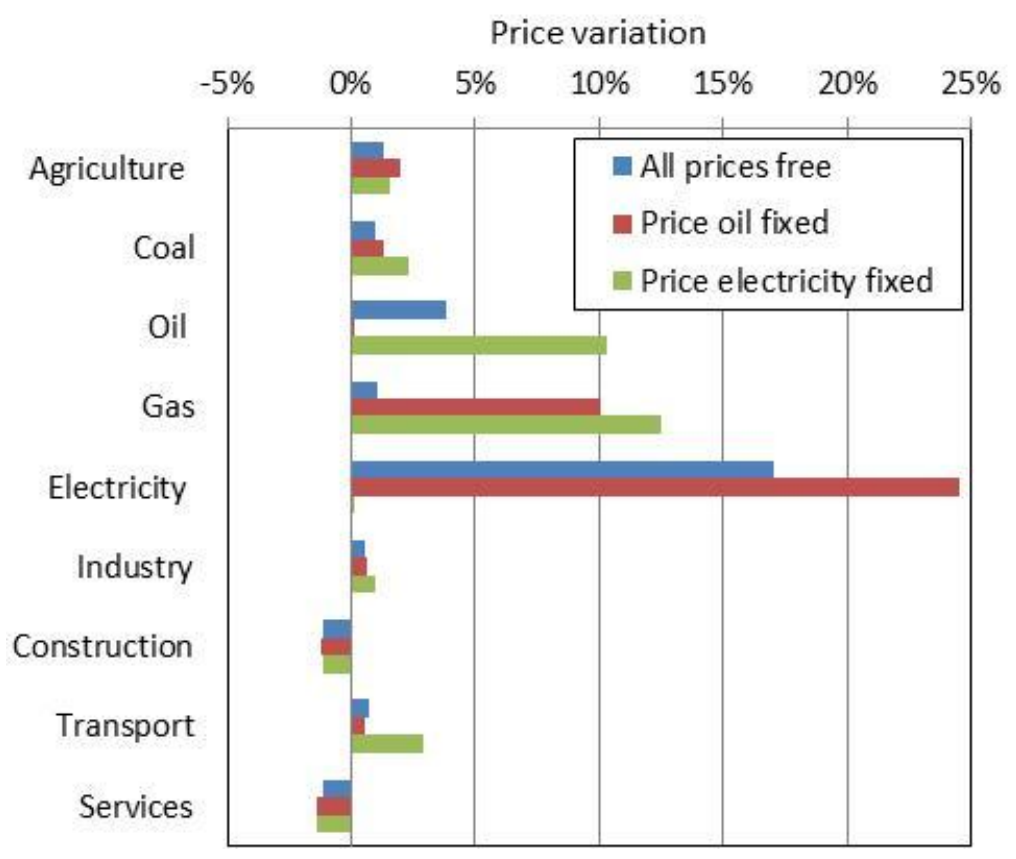

To illustrate the implications of doing this we conduct an analysis where we first fix the price of oil (red bar) and then the price of electricity (green bar). Fixing the price of oil would induce an increase in price of other energy goods (electricity would increase by $24.5 \%$ and gas by $10 \%$ ) and similarly if the price of electricity is fixed, oil would increase by $10.3 \%$ and gas by $12.5 \%$. Therefore, although it is possible to avoid particular effects on prices with tax exemptions it must be realized that the effect will be transferred to other parts of the economy (and the cost of $\mathrm{CO} 2$ reduction will also increase $\left.{ }^{24}\right)$. Therefore, the best way to overcome this barrier and avoid the

\footnotetext{
${ }^{23} \mathrm{~A} \mathrm{CO} 2$ tax of $€ 46.2 / \mathrm{tCO} 2$ is the level necessary to achieve a $15 \% \mathrm{CO} 2$ emission in the TAXL scenario.

${ }^{24}$ An analysis of the cost-effectiveness of $\mathrm{CO} 2$ tax exemptions can be found in Böhringer and Rutherford (1997) or González-Eguino (2011).
} 
potential loss of competitiveness in some specific energy/carbon intensive industries is to try to implement the tax reform (at least the $\mathrm{CO} 2$ tax part) in co-ordination with other trading partners.

A third reason, which is related to the second, is that an increase in the price of energy could have a regressive effect on households. Although, according to different studies, carbon taxes are not necessarily regressive there is often a concern that some of the poorest groups spend a higher percent of their income on energy than those who are better off. Therefore, an environmental tax reform should include measures to alleviate regressive effects. In that sense, there is another good policy implication of this study, because if the shadow economy is included the equity issues, in principle, should improve as more people move to the formal part of the economy.

The fourth and last reason is that policy-makers are not considering or exploiting the overall economic benefits of reducing emissions. Reducing $\mathrm{CO} 2$ emissions generates a positive economic externality and also ancillary benefits that have direct implications in health, agriculture and other issues that could be accounted for and that have an economic valuation. Table 4 illustrates the environmental benefits associated with the different environmental tax reforms considered for a $15 \%$ reduction in $\mathrm{CO} 2$ emissions using the standard coefficients ${ }^{25}$. As can be seen, a tax on $\mathrm{CO} 2$ reduces not only $\mathrm{CO} 2$ emissions but also other local pollutants. In the case of the LST and TaxK recycling scenarios local pollutants decrease more because GDP is decreasing and in the TaxL scenario they decrease less because it is increasing. The total damage avoided in terms of GDP is between 0.3 and $1.1 \%$ in the TaxL scenario and between 0.2 and $0.7 \%$ in the others. This is an extra economic benefit that could be taken into account so that environmental tax reforms can really be implemented.

\footnotetext{
${ }^{25}$ Damage from local pollutants is estimated specifically for Spain via the CASES Project (Markandya et al 2010), which accounts mostly for damage in health, agriculture and the building sector. The damage coefficients are the following (all measured in $€$ per tonne): SO2 (4,518), NOx $(3,229)$, NMVOC (740), NH3 $(4,936)$ and PPM (825). Damage from CO2-eq is estimated using a lower bound of $€ 17.2 / \mathrm{tCO} 2$-eq. and a higher bound of $€ 32$ as used by the European Commission (2008). CH4 and N20 are converted into CO-eq. based on their long-term global warming potentials.
} 
Table 4. Environmental impact and damage for a $15 \%$ reduction in $\mathrm{CO} 2$

\begin{tabular}{|c|c|c|c|}
\hline & \multicolumn{3}{|c|}{ Tax Recycling Method } \\
\hline & LST & Tax K & Tax L \\
\hline \multicolumn{4}{|c|}{ Environmental Impact (\% change in volumes) } \\
\hline $\mathrm{CO} 2$ & -15 & -15 & -15.00 \\
\hline $\mathrm{SO} 2$ & -3.5 & -3.6 & -0.80 \\
\hline NOX & -2.7 & -2.8 & 0.60 \\
\hline NMVOC & -3.5 & -3.8 & 0.00 \\
\hline $\mathrm{CH} 4$ & -3.1 & -3.2 & 0.00 \\
\hline $\mathrm{N} 2 \mathrm{O}$ & -3.7 & -4.1 & -0.50 \\
\hline NH3 & -4.2 & -4.7 & -1.00 \\
\hline PPM & -3.7 & -3.9 & -0.50 \\
\hline \multicolumn{4}{|l|}{ Damage avoided (M€) } \\
\hline CO2-eq. (High estimate) & 1818.8 & 1824.6 & 1752.2 \\
\hline CO2-eq. (Low estimate) & 977.6 & 980.7 & 941.8 \\
\hline Rest of Pollutants & 425 & 449.2 & 38.2 \\
\hline \multicolumn{4}{|l|}{ Total Damage as \% of GDP } \\
\hline High estimate $($ Base $=3.8 \%)$ & $2.90 \%$ & $2.90 \%$ & $2.70 \%$ \\
\hline Low estimate $($ Base $=2.4 \%)$ & $2.20 \%$ & $2.20 \%$ & $2.10 \%$ \\
\hline
\end{tabular}

\section{Concluding remarks}

Environmental fiscal reforms are proposed in literature as important policy tools for providing potentially important benefits for the economy, the environment and society. In this paper we link the analysis of an environmental fiscal reform with the existence of a shadow economy (and informal workers) and high unemployment. We are interested in shedding light on how an environmental fiscal reform may be useful for shifting from a shadow economy to a green economy where unemployment is reduced and the environment improves. This paper analyses this link between the "shadow economy" and the "green economy" using an Applied General Equilibrium model for the case of Spain, which has one of the highest unemployment rates in the developed world and one of the biggest informal economies of any wealthy country. 
The effects of a revenue-neutral $\mathrm{CO} 2$ tax reform are analysed by focusing on the revenue-recycling effect of using revenues from a $\mathrm{CO} 2$ tax to reduce taxes on labour or on capital or to make lump sum transfers. We use a standard AGE model that contains two features which are important regarding the labour market. First, there is involuntary unemployment and wages are determined endogenously following a wage curve. And second, formal and informal labour (which are substitutes in the production function) are linked through an equilibrium condition where expected wages in the two sectors are equal.

It can be concluded that the case for an environmental tax reform involving recycling via a labour tax reduction is strong. Assuming flexibility in the wage curve and in the formal and informal labour markets, we obtain a welfare gain (measured through Equivalent Variation, EV) of around $3 \%$ for a reduction in emissions of $15 \%$. Moreover, the official GDP could increase by $7 \%$, as long as workers in the shadow economy (informal workers) are brought into formal labour, and unemployment could be reduced by $3 \%$. If the ancillary benefits of the reduction in local pollutants are taken into account the total reduction in damage is between 0.3 and $1 \%$ of GDP.

Moreover, we isolate the extra benefits that can be expected if the shadow economy is incorporated into the existing literature on environmental fiscal reforms (in a standard AGE analysis with the unemployment modelled with wage curve). We estimate an extra amount of $1.5 \%$ in welfare, $1.4 \%$ in GDP and $6.1 \%$ in Official GDP. These results confirm that labour market conditions are important when analysing an environmental fiscal reform and that, considering its impacts, the shadow economy is too important to be neglected.

Of course, CGE models are highly stylised and we use a static model where dynamic effects are not taken into account. Hence we cannot expect a tax reform to generate the changes in one period, but rather to take a number of quarters. It is also important to note that welfare effects are dependent 
on the parameters assumed, especially the substitutability between formal and informal labour. Nevertheless, we carry out some sensitivity analyses for these parameters that confirm the sign of the welfare changes. Finally, it must be borne in mind that trade impacts are restricted in these models (following the Armington assumption) and effects on competitiveness are not fully incorporated. In any case, any reform of this kind would probably need to be pan-European to avoid negative impacts in some sectors.

An important aspect not considered in this paper that should be explored in future research is the distributional impact of environmental fiscal reform. Increases in the prices of $\mathrm{CO} 2$ and energy will generate regressive effects that need to be offset so that they are politically feasible. 


\section{References}

Ahn N. and S. de la Rica (1997), The underground economy in Spain: an alternative to unemployment? Applied Economics, 29, 733-743

Arrazola M., J. Hevia, I. Mauleón, and R. Sánchez (2010), Estimación del volumen de economía sumergida en España. Cuadernos de Información Económica, 220, pp. 81-88

Bajada C. and F. Schneider (2009), Unemployment and the Shadow Economy in the OECD, Review Economique, 60/4, 1011-1033

Babiker M.H., J.M. Reilly, M. Mayer, R.S. Eckaus, I. Sue Wing and R.C. Hyman (2001) The MIT Emissions Prediction and Policy Analysis (EPPA) Model: Revisions, Sensitivities, and Comparisons of Results. MIT Joint Program on the Science and Policy of Global Change, Report 71, Cambridge, Massachusetts.

Blanchflower D.G. and A.J. Oswald (1995), An introduction to the Wage Curve, Journal of Economic Perspectives, 9/3, 153-167.

Blanchflower D.G. and A.J. Oswald (2005), The Wage Curve Reload, IZA DP No.1665, pp. 1-47

Baumol, W.J., Oates, W.E., 1971. The use of standards and prices for protection of the environment, The Swedish Journal of Economics, 73, 42-54.

Böhringer C., Rutherford, T. (1997), Carbon Taxes with Exemptions in an Open Economy: A General Equilibrium Analysis of the German Tax Initiative, Journal of Environmental Economics and Management, 32, 2, 189-203.

Bayindir-Upmann, T. Raith,M.G. (2003) Should high-tax countries pursue revenue-neutral ecological tax reforms?, European Economic Review, 47, 1, 41-60

Bovenberg A.L., Goulder L.H. (1996), Optimal environmental taxation in the presence of other taxes: general equilibrium analyses, American Economic Review, no. 86, 1996, pages 985-1000.

Buehn A. and F. Schneider (2011), Shadow economies around the world: novel insights, accepted knowledge, and new estimates. International Tax and Public Finance, 1-33

Carraro, C., Galeotti, M., Gallo, M., 1996. Environmental taxation and unemployment: some evidence on the double dividend hypothesis in Europe. Journal of Public Economics 62, 141181.

Eurostat (2005) Energy and environment statistics, European Statistic Office, www.eurostat.es.

European Commission (2008). Commission Staff Working Document - Impact Assessment Document accompanying the Package of Implementation measures for the EU's objectives on Climate change and renewable energy for 2020. SEC(2008) 85/3.

Faehn T., A. Gómez-Plana and S. Kverndokk, (2009), Can a carbon permit system reduce Spanish unemployment? Energy Economics, 31, 4, 595-604 
Feld L.P. and F. Schneider (2010), Survey on the Shadow Economy and Undeclared Earnings in OECD Countries. German Economic Review, 11(2), 109-149.

González-Eguino M. (2011), The importance of the design of Market-Based Instruments for CO2 mitigation: an AGE analysis for Spain. Ecological Economics. 70, 2292-2302.

Goulder, L.H., 1995. Environmental Taxation and the 'double dividend': A reader's guide. International Tax and Public Finance, 2, 157-184.

Harris J.R. and M. Todaro (1970), Migration, Unemployment and Development: A two sector Analysis, The American Economic Review, 60, 1, 126-142

Hvidtfeldt C., B. Jensen and C. Larsen (2011), Undeclared work and the Danes, University Press of Southern Denmark, June 2010, English summary reported in: Rockwool Foundation Research Unit, News, March 2011, Copenhagen, Denmark.

INE (2009a). Contabilidad Nacional de España. Base 2000. Marco input-output. Tabla simétrica, Año 2005. Instituto Nacional de Estadística. www.ine.es.

INE (2009b). Cuentas satélite sobre emisiones atmosféricas. Año 2005. Instituto Nacional de Estadística. www.ine.es.

Kosquela, E. \& R. Schöb, 1999, "Alleviating Unemployment: the Case for Green Tax Reform", European Economic Review, 43, 1723-1746.

Majocchi, A., 1996. Green fiscal reform and employment: a survey. Environmental and Resource Economics 8, 375-397.

Manresa, A. and F. Sancho (2005), Implementing a double dividend: recycling ecotaxes towards lower labour taxes, Energy Policy, 33, 1577-1585.

Markandya, A., A. Bigano and R. Porchia (eds.) (2010) “The Social Costs of Electricity: Scenarios and Policy Implications", Edward Elgar Publishing.

Markandya, A. (2011), Environmental Taxation: What Have We Learnt in the Last 30 years? Rivista di Politica Economica, VII-IX, 11-58.

Markandya A., Gonzalez-Eguino, M., Escapa, M. (2012). Environmental fiscal reform and unemployment in Spain, Critical Issues in Environ.mental Taxation, Edward Elgar Publishing. Forthcoming.

Labandeira, X., Labeaga, JM., Rodríguez, M. (2004) Green Tax Reforms in Spain, Green Tax Reforms in Spain, European Environment, 14 (2004): 290-299.

Pearce D. (1991) The Role of Carbon Taxes in Adjusting to Global Warming», Economic Journal, no. 101, 1991, pages 938-948.

Pissarides, C.A (1998) The impact of employment tax cuts on unemployment and wages; The role of unemployment benefits and tax structure, European Economic Review, 42, 1, 155-183. 
Rutherford T. and M. Light (2002), A General Equilibrium Model for Tax Policy Analysis in Colombia: The MEGATAX Model, Working paper.

OECD (2009), Is Informal Normal? Towards More and Better Jobs, OECD, París

Schneider F. (2011), The Shadow Economy and Shadow Economy Labor Force: What Do We (Not) Know? IZA Discussion Paper No. 5769. Forthcoming in World Economics 2012

Schneider F., Buehn, A., Montenegro, C. (2010) "Shadow economies all over the world: new estimates for 162 countries from 1999 to 2007”, Policy research Working Paper, World Bank.

Schneider F. and D. Enste (2000), Shadow Economies: Size, Causes and Consequences, Journal of Economic Literature, 38, 77-114

Schneider, K., 1997. Involuntary unemployment and environmental policy: The double dividend hypothesis. Scandinavian Journal of Economics 99, 45-59.

Shoven, J., J. Whalley (1992) Applying general equilibrium, Cambridge University Pres. 
APPENDIX

Table A1: Extended Input-Output Table with informal labour (LI), 2005

\begin{tabular}{|c|c|c|c|c|c|c|c|c|c|c|c|c|c|c|c|}
\hline & S1 & $\mathrm{S} 2$ & S3 & S4 & S5 & S6 & S7 & S8 & S9 & C & G & 1 & $\mathrm{M}$ & $x$ & Total \\
\hline Agriculture & 46157 & -1 & -17744 & -4941 & -1 & -29880 & -1488 & -310 & -3142 & -12496 & 0 & -871 & 33456 & -8739 & 0 \\
\hline Coal & -15 & 984 & -100 & -4 & -1887 & -362 & 0 & -5 & -75 & -195 & 0 & -14 & 1678 & -5 & 0 \\
\hline Oil & -940 & -30 & 25372 & -29 & -3072 & -4791 & -484 & -6496 & -2842 & -8355 & 0 & -219 & 9369 & -7483 & c \\
\hline Gas & -54 & -1 & -500 & 7774 & -3146 & -1940 & -20 & -147 & -1053 & -3200 & 0 & -1 & 2399 & -111 & \\
\hline Electricity & $\begin{array}{r}-719 \\
\end{array}$ & -88 & -73 & $\begin{array}{l}-29 \\
17\end{array}$ & 26402 & $\begin{array}{r}-7720 \\
61014\end{array}$ & $\begin{array}{r}-526 \\
-\end{array}$ & $\begin{array}{l}-1676 \\
-16703\end{array}$ & -9426 & $\begin{array}{r}-6219 \\
115109\end{array}$ & $\begin{array}{r}0 \\
7\end{array}$ & $\begin{array}{r}-10 \\
\end{array}$ & $\begin{array}{r}502 \\
\end{array}$ & $\begin{array}{r}-418 \\
-42957\end{array}$ & 0 \\
\hline Industry & -10406 & -239 & -308 & -17 & -1530 & 261044 & -54468 & -9293 & -68376 & -115409 & -7033 & -55744 & 191306 & -129527 & \\
\hline Construction & -271 & -4 & -32 & -16 & -435 & -1836 & 200192 & -2190 & -20687 & -28831 & 0 & -145897 & 16 & -9 & 0 \\
\hline Transport & -1190 & -52 & -813 & -26 & -1145 & -25228 & -3535 & 103128 & -28295 & -33748 & -2087 & -216 & 10501 & -17294 & \\
\hline Services & -4040 & -79 & -1313 & -240 & -3901 & -61133 & -22551 & -21955 & 781145 & -454975 & -162173 & -42363 & 27811 & -34233 & 0 \\
\hline LF & -5058 & -301 & -391 & -198 & -1270 & -57164 & -40779 & -18002 & -211258 & 334421 & 0 & 0 & 0 & 0 & \\
\hline LI & -3035 & -30 & -39 & -20 & -127 & -11433 & -24467 & -3600 & -126755 & 169506 & 0 & 0 & 0 & 0 & \\
\hline K & -19559 & -60 & -3227 & -2115 & -9099 & -41994 & -36758 & -30947 & -231806 & 375565 & 0 & 0 & 0 & 0 & \\
\hline TAXK & 0 & -3 & -702 & -68 & -284 & 0 & -2454 & -3208 & -18210 & 0 & 24929 & 0 & 0 & 0 & 0 \\
\hline TAXL & -870 & -96 & -130 & -71 & -505 & -17563 & -12662 & -5299 & -59220 & 0 & 96416 & 0 & 0 & 0 & 0 \\
\hline TAXLS & 0 & 0 & 0 & 0 & 0 & 0 & 0 & 0 & 0 & -49948 & 49948 & & & & \\
\hline Savings & 0 & 0 & 0 & 0 & 0 & 0 & 0 & 0 & 0 & -245335 & 0 & 245335 & 0 & 0 & 0 \\
\hline$X D$ & 0 & 0 & 0 & 0 & 0 & 0 & 0 & 0 & 0 & 79219 & 0 & 0 & -277038 & 197819 & 0 \\
\hline Total & 0 & 0 & 0 & 0 & 0 & 0 & 0 & 0 & 0 & 0 & 0 & 0 & 0 & 0 & \\
\hline
\end{tabular}

Source: INE (2009a) and own work 
Table A2: Sectoral output and production factors, 2005

\begin{tabular}{|c|c|c|c|c|c|c|c|c|c|c|}
\hline & \multirow{2}{*}{$\begin{array}{c}\text { Input-Output Table } \\
\text { Sectoral Codes }\end{array}$} & \multicolumn{2}{|c|}{ Production } & \multicolumn{2}{|c|}{ Capital } & \multicolumn{2}{|c|}{ Formal Labour } & \multicolumn{3}{|c|}{ Informal Labour } \\
\hline & & $(\mathrm{M} €)$ & $(\%)$ & $(\mathrm{M} €)$ & $(\%)$ & $(\mathrm{M} €)$ & $(\%)$ & $(\mathrm{M} €)$ & $(\%)$ & Category \\
\hline Agriculture & $1-3,5-7$ & 46157 & $(3.2 \%)$ & 19559 & $(5.2 \%)$ & 5058 & $(1.5 \%)$ & 3035 & $(1.8 \%)$ & high \\
\hline Coal & 4 & 984 & $(0.1 \%)$ & 60 & $(0.0 \%)$ & 301 & $(0.1 \%)$ & 30 & $(0.0 \%)$ & low \\
\hline Oil & 8 & 25372 & $(1.7 \%)$ & 3227 & $(0.9 \%)$ & 391 & $(0.1 \%)$ & 39 & $(0.0 \%)$ & low \\
\hline Gas & 10 & 7774 & $(0.5 \%)$ & 2115 & $(0.6 \%)$ & 198 & $(0.1 \%)$ & 20 & $(0.0 \%)$ & low \\
\hline Electricity & 9 & 26402 & $(1.8 \%)$ & 9099 & $(2.4 \%)$ & 1270 & $(0.4 \%)$ & 127 & $(0.1 \%)$ & low \\
\hline Industry & $11,12-39$ & 261044 & $(18.0 \%)$ & 41994 & $(11.2 \%)$ & 57164 & $(17.1 \%)$ & 11433 & $(7.0 \%)$ & medium \\
\hline Construction & 40 & 200192 & $(13.8 \%)$ & 36758 & $(9.8 \%)$ & 40779 & $(12.2 \%)$ & 24467 & $(14.9 \%)$ & high \\
\hline Transport & $46-52$ & 103128 & $(7.1 \%)$ & 30947 & $(8.2 \%)$ & 18002 & $(5.4 \%)$ & 3600 & $(2.2 \%)$ & medium \\
\hline Services & $41-45,53-73$ & 781145 & $(53.8 \%)$ & 231806 & $(61.7 \%)$ & 211258 & $(63.2 \%)$ & 126755 & $(77.3 \%)$ & high \\
\hline Total & & 1452198 & $(100 \%)$ & 375565 & $(100 \%)$ & 334421 & $(100 \%)$ & 164073 & $(100 \%)$ & \\
\hline
\end{tabular}

Source: INE (2009a) and own work.

Note: the sectors with low, medium and high participation of informal labour are classified following Hvidtfeldt et al (2011). It is assumed that 10 (low), 20 (medium) and 60\% (high) of labour is not declared in those sectors and therefore can be classed as informal labour. In total, the shadow economy accounts for $20 \%$ of official GDP in 2005. 
Table A3: Sectoral CO2 and other local pollutant emissions, 2005

\begin{tabular}{|l|l|r|r|r|r|r|r|r|r|}
\hline & Environmental Accounts & \multicolumn{1}{c}{$\begin{array}{c}\text { SOx } \\
\text { (ton) }\end{array}$} & \multicolumn{1}{c|}{$\begin{array}{c}\text { NOx } \\
\text { (ton) }\end{array}$} & $\begin{array}{r}\text { COVNM } \\
\text { (ton) }\end{array}$ & $\begin{array}{r}\text { CH4 } \\
\text { (ton) }\end{array}$ & $\begin{array}{r}\text { CO2 } \\
\text { (Kton) }\end{array}$ & $\begin{array}{r}\text { N2O } \\
\text { (ton) }\end{array}$ & $\begin{array}{c}\text { NH3 } \\
\text { (ton) }\end{array}$ & $\begin{array}{r}\text { PM10 } \\
\text { (ton) }\end{array}$ \\
\hline Agriculture & AB+CA.2+CB & 31144 & 198218 & 1118429 & 952798 & 12192 & 49690 & 338643 & 49176 \\
Coal & CA.1 & 4802 & 856 & 62 & 11436 & 338 & 9 & 0 & 434 \\
Oil & DF & 113149 & 45311 & 16597 & 6753 & 19952 & 453 & 400 & 6606 \\
Gas & E.2 & 7 & 2874 & 310 & 13 & 235 & 5 & 0 & 22 \\
Electricity & E.1 & 928501 & 322903 & 11336 & 22779 & 109186 & 1867 & 1 & 21865 \\
Industry & E.3+D-DF & 109037 & 238467 & 364130 & 57154 & 93557 & 6534 & 13819 & 20491 \\
Construction & F & 148 & 65042 & 102683 & 291 & 5316 & 118 & 15 & 488 \\
Transport & I & 54895 & 271918 & 48672 & 24209 & 35402 & 761 & 89 & 11771 \\
Services & G+H+J+K+L+M+N+O+95 & 8235 & 56529 & 60057 & 572802 & 12354 & 5481 & 6842 & 2165 \\
\hline Households & & 15991 & 229691 & 219901 & 36914 & 76357 & 2874 & 7417 & 33728 \\
\hline Total & & 1265909 & 1431808 & 1942177 & 1685149 & 364888 & 67793 & 367226 & 146745 \\
\hline
\end{tabular}

Source: INE (2009b) and own work 
Table A4: Sectoral CO2 disaggregation by different sources in $\%, 2005$

\begin{tabular}{lrrr}
\hline & Coal & Oil & Gas \\
\hline Agriculture & 3 & 96 & 1 \\
Coal & - & 97 & 3 \\
Oil & 30 & - & 70 \\
Gas & 0 & 100 & - \\
Electricity & 55 & 25 & 20 \\
Industry & 10 & 70 & 20 \\
Construction & 0 & 97 & 3 \\
Transport & 0 & 100 & 0 \\
Services & 0 & 80 & 20 \\
Households & 3 & 75 & 22 \\
\hline Total & 22 & 58 & 20 \\
\hline
\end{tabular}

Source: Eurostat (2005), INE (2009b) and own work

Table A5: Elasticities of substitution in production, trade and consumption

\begin{tabular}{llc}
\hline$\sigma^{Y}$ & Elasticity of substitution between material inputs and Capital-Labour-Energy & 0 \\
$\sigma^{K L E}$ & Elasticity of substitution between Capital-Labour and Energy & 0.25 \\
$\sigma^{K L}$ & Elasticity of substitution between Capital and Labour & 1 \\
$\sigma^{L}$ & Elasticity of substitution between Formal and Informal Labour & 5 \\
$\sigma^{E}$ & Elasticity of substitution between Electricity and Fossil Fuels & 0.5 \\
$\sigma^{F}$ & Elasticity of substitution between Coal, Oil and Gas & 1 \\
$\sigma^{A}$ & Elasticity of substitution between domestic and imported goods & 3 \\
$\sigma^{T}$ & Elasticity of transformation between domestic goods and exports & 3 \\
$\sigma^{C}$ & Elasticity of substitution between consumption of energy and non energy goods & 0.5 \\
$\sigma^{C E}$ & Elasticity of substitution in consumption of energy goods & 1 \\
$\sigma^{C B}$ & Elasticity of substitution in consumption of non energy goods & 1 \\
\hline
\end{tabular}

Source: MIT-EPPA Babiker et al. (2001). The value for $\sigma^{L}$ is our own. 


\title{
BC3 WORKING PAPER SERIES
}

\author{
Basque Centre for Climate Change (BC3), Bilbao, Spain
}

The BC3 Working Paper Series is available on the internet at the following addresses:

http://www.bc3research.org/lits_publications.html

$\underline{\text { http://ideas.repec.org/s/bcc/wpaper.html }}$

BC3 Working Papers available:

2011-02

Dirk Rübbelke: International Support of Climate Change Policies in Developing Countries: Strategic, Moral and Fairness Aspects

Melanie Heugues: Endogenous Timing in Pollution Control: Stackelberg versus Cournot-Nash Equilibria

2011-04

2011-05

Karen Pittel and Dirk Rübbelke: International Climate Finance and its Influence on Fairness and Policy

Wan-Jung Chou, Andrea Bigano, Alistair Hunt, Stephane La Branche, Anil Markandya, Roberta Pierfederici: Households' WTP for the Reliability of Gas Supply

Roger Fouquet and Peter J.G. Pearson: The Long Run Demand for Lighting: Elasticities and Rebound Effects in Different Phases of Economic Development

Ibon Galarraga, David Heres Del Valle and Mikel González-Eguino: Price Premium for High-Efficiency Refrigerators and Calculation of Price-Elasticities for Close-Substitutes: Combining Hedonic Pricing and Demand Systems

Anil Markandya, Mikel González-Eguino, Patrick Criqui, Silvana Mima: Low Climate Stabilisation under Diverse Growth and Convergence Scenarios

Martin Altemeyer-Bartscher, Anil Markandya and Dirk Rübbelke: The Private Provision of International Impure Public Goods: the Case of Climate Policy

Aline Chiabai, Ibon Galarraga, Anil Markandya and Unai Pascual: The Equivalency Principle for Discounting the Value of Natural Assets: An Application to an Investment Project in the Basque Coast

Roger Fouquet: The Demand for Environmental Quality in Driving Transitions to Low Polluting Energy Sources

Joseph V. Spadaro: The Uniform World Model: A Methodology for Predicting the Health Impacts of Air Pollution

Thomas Heyd: Climate Change, Responsibilities, and Defeatism and Complacency 